Article

\title{
The Impact of Implied Volatility Fluctuations on Vertical Spread Option Strategies: The Case of WTI Crude Oil Market
}

\author{
Bartosz Łamasz *(D) and Natalia Iwaszczuk (D) \\ Faculty of Management, AGH University of Science and Technology, 30-059 Cracow, Poland; \\ niwaszcz@zarz.agh.edu.pl \\ * Correspondence: blamasz@zarz.agh.edu.pl; Tel.: +48-696-668-417
}

Received: 31 July 2020; Accepted: 7 October 2020; Published: 13 October 2020

check for updates

\begin{abstract}
This paper aims to analyze the impact of implied volatility on the costs, break-even points (BEPs), and the final results of the vertical spread option strategies (vertical spreads). We considered two main groups of vertical spreads: with limited and unlimited profits. The strategy with limited profits was divided into net credit spread and net debit spread. The analysis takes into account West Texas Intermediate (WTI) crude oil options listed on New York Mercantile Exchange (NYMEX) from 17 November 2008 to 15 April 2020. Our findings suggest that the unlimited vertical spreads were executed with profits less frequently than the limited vertical spreads in each of the considered categories of implied volatility. Nonetheless, the advantage of unlimited strategies was observed for substantial oil price movements (above 10\%) when the rates of return on these strategies were higher than for limited strategies. With small price movements (lower than $5 \%$ ), the net credit spread strategies were by far the best choice and generated profits in the widest price ranges in each category of implied volatility. This study bridges the gap between option strategies trading, implied volatility and WTI crude oil market. The obtained results may be a source of information in hedging against oil price fluctuations.
\end{abstract}

Keywords: crude oil price risk; implied volatility; vertical spread option strategies

\section{Introduction}

Changes in oil prices are a factor that directly influences the decisions of manufacturers and consumers, both individual and institutional. Their reactions, in turn, translate to the financial markets and thus affect the overall economy. The impact of oil price fluctuations on other markets is also noticeable. This is linked to the fact that crude oil simultaneously fulfills two essential functions. The first is a consequence of the oil consumption in almost every branch of economic activity [1]. Second, oil and its derivative products are traded in financial markets. This makes it possible to invest in crude oil as in other commodities (e.g., gold, silver), stock markets, or foreign exchange markets.

There is a large number of studies concerning the impact of crude oil prices and volatility in oil prices on various groups of commodities. Ewing and Malik [2], using univariate and bivariate generalized autoregressive conditional heteroscedasticity $(\mathrm{GARCH})$ models, indicated strong evidence of significant transmission of volatility between gold and oil returns. Chen and $\mathrm{Xu}$ [3] showed that Brent and gold prices' dependent structure are more complex than those of West Texas Intermediate (WTI) and gold. Research on the links between oil and gold prices results, among others both of these raw materials are assigned important roles in the risk management process in financial markets [4]. There are also many works focused on the dependence of oil prices on other commodities such as silver, platinum, and palladium [5], copper, zinc, and molybdenum [6]; agricultural commodities [7-10]; 
as well as energy products and raw materials, including natural gas [11-15]. There are also findings that show that crude oil price volatility has a significant impact on price indexes for energy and non-energy commodities [16,17]. These interactions changed dynamically over time, and many of the above-mentioned studies underline the growing importance of oil price fluctuations for particular groups of commodities, especially after the global financial crisis in 2008. Demiralay et al. [18] investigated the dynamic equicorrelations (DECO) and spillover effects among WTI crude oil, natural gas, heating oil, and gasoline futures markets using a multivariate fractionally integrated asymmetric power ARCH-DECO-GARCH model and the spillover index technique. They showed a strong evidence of heightened equicorrelations at such times of financial turmoil as 11 September 2001, the global financial crisis of 2008, and the 2014-2016 oil oversupply.

Despite differences in chemical and physical properties, oil price volatility also affects the development of prices for other types of this raw material. Liu and Gong [19] investigated the time-varying volatility spillover effect between four major benchmarks in the crude oil markets, including WTI (North America), Brent (North Sea), Oman (Middle East), and Tapis (Asia-Pacific). They showed, using the time-varying parameter VAR model with stochastic volatility, that the links between crude oil prices' volatility are getting increasingly stronger when there are some cyclical deviations from the trend.

The oil market also plays an essential role in foreign exchange markets. Since the US dollar (USD) is the major invoicing and settlement currency in international oil markets, the existence of a strong link between these two markets seems apparent [20]. The oil market also affects exchange rates, mainly in the countries that largely depend on oil for their trade. An increase in oil price quotations usually leads to an appreciation of the oil-exporting currencies and a depreciation of the currencies of the oil-importing countries [21]. For volatility spillovers between oil and the currency markets, the relations are even more complex. Zhang et al. [22], using econometric techniques, showed that the instant fluctuation in the US dollar exchange rate would not significantly change the WTI crude oil market. Nevertheless, later studies showed that the volatility spillover effect does occur for some of the currencies and becomes apparent, especially at times of high volatility values in the oil market, such as just before the collapse of the markets in 2008 [23].

The issue of the volatility spillover in stock markets (especially in developed and developing countries [24]) has been the subject of research for many years. As practically every sector of the modern economy is dependent on oil prices, their impact on equity markets has also been investigated. Recent research has shown that an increase in oil prices also affects the financial performance of companies outside the oil sector as it translates into an increased cost of energy. In turn, this has a negative impact on equity returns for all sectors except mining, oil, and gas industries [25-27]. Hsiao et al. [28] showed that oil price has a significant impact on the stock prices of China's renewable energy listed companies. They also found strong evidence that crude oil price volatility has a spillover effect on stock price variations. The strong volatility link between crude oil prices and stock returns became noticeable after introducing oil futures contracts to the financial markets. Positions in these contracts are now being opened by both oil companies that want to hedge themselves against oil price fluctuations and non-oil companies that use these contracts to diversify the risk associated with changes in the prices of other instruments (incl. stock prices). Malik, Hammoudeh [29], Arouri et al. [30], and Maghyereh and Avartani [31] conducted research on the impact of oil price volatility on stock markets. The outcomes of their research revealed the significant influence of oil price volatility on stock markets in such countries and regions as the USA, Saudi Arabia, Kuwait, Bahrain, and North Africa. Similar conclusions were reached by Arouri et al. [32] concerning stock prices of European companies in the period 1998-2009.

As seen above, literature studies show that volatility spillover effect of oil prices to other markets is a commonly observed phenomenon, particularly noticeable in sudden price movements. One of the volatility measures that is a frequent subject of scientific studies and a subject of interest to investors is implied volatility. It is a concept associated with the options market and obtained from the 
transformation of formulae that calculates the theoretical value of an option with the actual market option price. One of the most commonly used models for this purpose is the Black-Scholes model [33]. The Black option pricing formula is used for commodity options [34].

The growing importance of implied volatility caused that 68 implied volatility indices cover a broad base of asset classes [35]. Many studies examine the volatility spillover effects in the international financial markets for these indices [36-42]. Another set of studies explores the association between volatility indices and the underlying market returns [43-47]. A handful of academic studies have also investigated the ability of implied volatilities to forecast realized volatility. A review of forecasting volatility literature can be found in Blair et al. [48], Poon and Granger [49,50], and Gonzalez-Perez [51].

The studies show that the implied volatility plays an important role from the perspective of effective risk management and investment portfolios. The growing importance of implied volatility on financial markets and the consequences of significant fluctuations in oil prices were the main motivations to examine how changes of implied volatility affect the costs and final results of given options strategies. In this study we focus on the options strategies that, in our opinion, are the tools that, if used wisely, give a chance to hedge against the risk of price changes.

There is only a handful of studies that analyze the possibilities of using option strategies from the perspective of hedging against the price risk [52-55]. Nevertheless, they focus on the possibilities of using various types of options, including vanilla options or barrier options. Thus, they do not take into account the level of implied volatility, which affects the strategies costs.

To the best of our knowledge, there is only one study that takes into consideration the level of implied volatility while choosing the option strategy [56]. However, the authors of this work focus on making trading decisions on the option market based on the predicted value of volatility.

In our opinion, it is the implied volatility that should be taken into consideration when choosing an option strategy as it may have a great impact on the final hedging results. Therefore, for the purpose of this study, we used implied volatility, calculated by using the Black formula. The presented categories of implied volatility were determined by the frequency of occurrence of a given level of volatility in the WTI options market. The analyzed strategies were the vertical spread option strategies with limited losses (vertical spreads).

The remainder of the article is organized as follows. Section 2 presents the main facts about Vertical spreads and the classification used in the empirical analysis. Section 3 provides the data (WTI crude oil prices, implied volatility) and reports their statistical properties. Our empirical results are introduced in Section 4. This section is divided into three parts: Section 4.1 gives information about the cost level in the vertical spreads for each category of implied volatility, Section 4.2 analyzes the frequency of execution the strategies with profits, and Section 4.3 analyzes the final results of the strategies for different levels of oil price change. Section 5 provides the summary conclusions and future research directions.

\section{Vertical Spread Option Strategies}

For options traders, one of the key aspects is the level of option premium. For the option holder (buyer), it is the maximum loss they may incur due to the right to decide whether to exercise the option or let it expire without exercising it at a specified date in the future (the expiry date). For the option writer (seller), the option premium is the maximum profit they will make when the option expires without being exercised. Combining options with different parameters makes it possible to construct option strategies, including vertical spreads.

A vertical spread is an options strategy that requires buying and selling options of the same type (calls or puts):

- with the same expiration date;

- $\quad$ with the same underlying asset;

- $\quad$ but with different strike prices. 
There are eight types of vertical spread strategies, i.e., bull call spread, bear put spread, bull put spread, bear call spread, bull put ladder, bear call ladder, bull call spread, and bear put ladder [57]. Since the last two allow for unlimited losses, they would not be analyzed for the purpose of this study. The most important information on the other six strategies is provided in Table 1.

Table 1. Characteristics of vertical spread option strategies.

\begin{tabular}{|c|c|c|c|}
\hline Name of the Strategy & Component Parts & Maximum Loss & Maximum Profit \\
\hline Bull Call Spread & $\begin{array}{ll}\text { - } & \text { Buy call option with strike price } K_{1} \\
\text { - } & \text { Sell call option with strike price } K_{2} \\
\text { - } & \text { ATM }<K_{1}<K_{2} \\
& \text { Net debit spread }\end{array}$ & $c\left(K_{1}\right)-c\left(K_{2}\right)$ & $K_{2}-K_{1}-\left[c\left(K_{1}\right)-c\left(K_{2}\right)\right]$ \\
\hline Bear Put Spread & $\begin{array}{ll}\text { - } & \text { Sell put option with strike price } K_{1} \\
\text { - } & \text { Buy put option with strike price } K_{2} \\
\text { - } & K_{1}<K_{2}<\text { ATM } \\
\text { - } & \text { Net debit Spread }\end{array}$ & $p\left(K_{2}\right)-p\left(K_{1}\right)$ & $K_{2}-K_{1}-\left[p\left(K_{2}\right)-p\left(K_{1}\right)\right]$ \\
\hline Bull Put Spread & $\begin{array}{ll}\text { - } & \text { Buy put option with strike price } K_{1} \\
\text { - } & \text { Sell put option with strike price } K_{2} \\
\text { - } & K_{1}<K_{2}<\text { ATM } \\
\text { - } & \text { Net credit Spread }\end{array}$ & $K_{2}-K_{1}-\left[p\left(K_{2}\right)-p\left(K_{1}\right)\right]$ & $p\left(K_{2}\right)-p\left(K_{1}\right)$ \\
\hline Bear Call Spread & $\begin{array}{ll}\text { - } & \text { Sell call option with strike price } K_{1} \\
\text { - } & \text { Buy call option with strike price } K_{2} \\
\text { - } & \text { ATM }<K_{1}<K_{2} \\
\text { - } & \text { Net credit Spread }\end{array}$ & $K_{2}-K_{1}-\left[c\left(K_{2}\right)-c\left(K_{1}\right)\right]$ & $c\left(K_{1}\right)-c\left(K_{2}\right)$ \\
\hline Bull Put Ladder & $\begin{array}{ll}\text { - } & \text { Buy put option with strike price } K_{1} \\
\text { - } & \text { Buy put option with strike price } K_{2} \\
\text { - } & \text { Sell put option with strike price } K_{3} \\
\text { - } & K_{1}<K_{2}<K_{3}<\text { ATM }\end{array}$ & $\begin{array}{c}p\left(K_{1}\right)+p\left(K_{2}\right)-p\left(K_{3}\right)+ \\
\left(K_{3}-K_{2}\right)\end{array}$ & $\begin{array}{c}K_{1}+K_{2}-K_{3}-F- \\
p\left(K_{1}\right)-p\left(K_{2}\right)+p\left(K_{3}\right)\end{array}$ \\
\hline Bear Call Ladder & $\begin{array}{ll}\text { - } & \text { Sell call option with strike price } K_{1} \\
\text { - } & \text { Buy call option with strike price } K_{2} \\
\text { - } & \text { Buy call option with strike price } K_{3} \\
\text { - } & \text { ATM }<K_{1}<K_{2}<K_{3}\end{array}$ & $\begin{array}{c}c\left(K_{3}\right)+c\left(K_{2}\right)-c\left(K_{1}\right)+ \\
\left(K_{2}-K_{1}\right)\end{array}$ & $\begin{array}{c}K_{1}-K_{2}-K_{3}+F+ \\
c\left(K_{1}\right)-c\left(K_{2}\right)+c\left(K_{3}\right)\end{array}$ \\
\hline
\end{tabular}

A value that is crucial to the success of the strategy is its break-even point (BEP). It is the price of the underlying asset (WTI crude oil price) for which the outcome of the strategy is zero. In the case of the bear put spread, bear call spread, bull put spread, and bull call spread strategies, there is always one BEP. In the bull put ladder and bear call ladder strategies, there can be one or two BEPs. The occurrence of this second BEP depends on whether the difference between the option premiums paid (due to buying an option) and received (due to selling an option) is less or greater than zero.

A limited level of losses characterizes all of the strategies discussed later in this paper. It is also noteworthy that each strategy's structure uses two or three options that are always out of the money (OTM) options. The option premium determined for such options is lower than for at the money (ATM) and in the money (ITM) options, which is conducive to reducing the costs (maximum losses) in vertical spreads. In the bull call spread, bear put spread, bull put spread, and bear put spread, the generated maximum profit is also limited. As a result, these are cheaper strategies than bull put ladder or bear call ladder in which the profit is unlimited, providing that the price trend for the underlying asset is correctly predicted (bull put ladder-if prices decline; bear call ladder-if prices increase). Thus, these six strategies can be divided into two main categories (see Figure 1). The first comprises bull call spread, bear put spread, bull put spread, and bear put spread, referred to as "limited strategies". The second group comprises bull put ladder and bear call ladder strategies, referred to as "unlimited strategies". It is also worth noting that two subcategories can be distinguished in the limited strategies depending on whether the difference between the option premium paid (due to buying an option) and the premium received (due to selling an option) was positive or negative. The bear put spread and 
bull call spread strategies are commonly referred to as net debit spread, while the bear call spread and bull put spread are referred to as net credit spread. In the case of net debit spread, the buyer of the strategy bears a cost equal to the maximum possible loss at the time of opening. On the other hand, in net credit spreads, the aim is to defend the amount that is received at the time of opening a position in the strategy, which is the maximum profit that can be generated in this strategy.

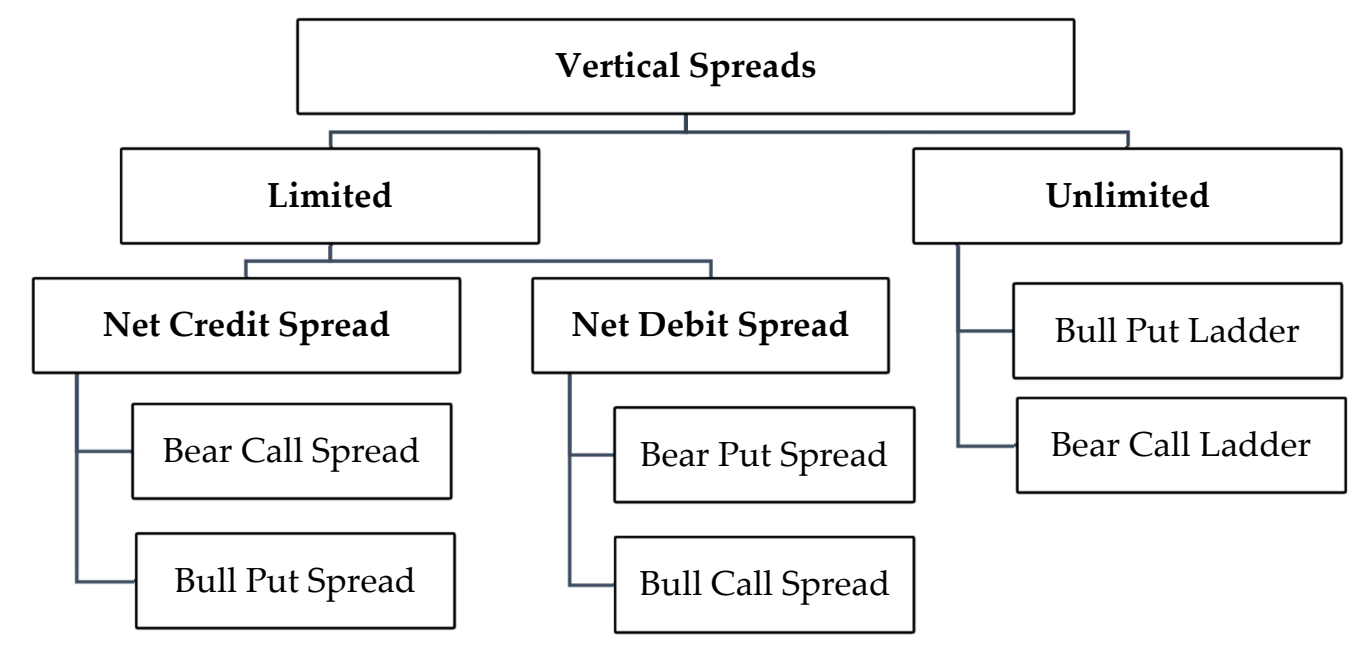

Figure 1. Classification of the vertical spread option strategies.

\section{Data and Preliminary Analysis}

The empirical part of the paper focuses on WTI crude oil prices and WTI crude oil European financial options listed on the New York Mercantile Exchange (NYMEX) in the period from 17 November 2008 to 15 April 2020. The ATM options data were sourced from the QuikStrike platform provided by Chicago Mercantile Exchange (CME) Group [58]. We use the value of implied volatility of ATM options for 2871 observations. The number of days left to the expiration of analyzed options varied from 34 days to one day. The option contract expired three business days prior to the underlying light sweet crude oil futures (CL). For the NYMEX, trading on the CL, contracts terminate third business day prior to the 25 th calendar day of the month prior to the contract month. WTI crude oil prices and the implied volatility of ATM options are presented in Figure 2.

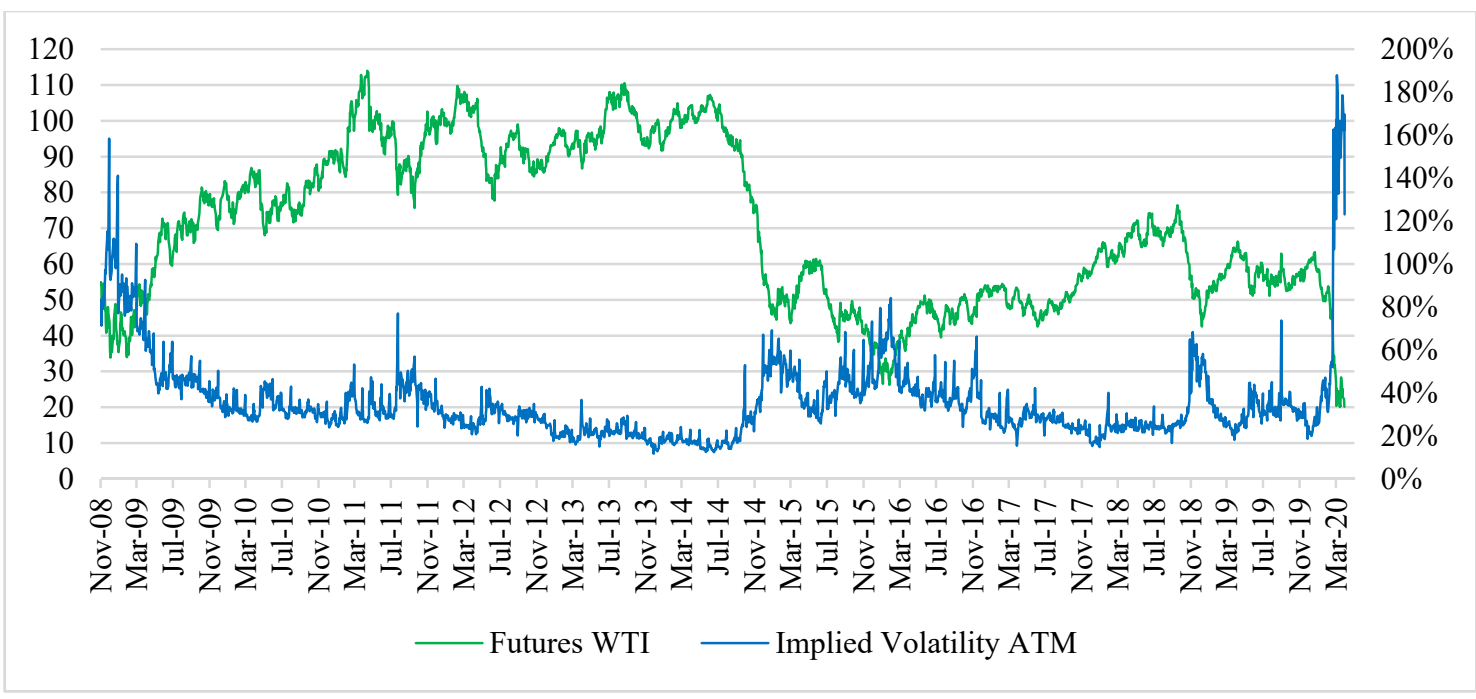

Figure 2. Plots of raw data. The left axis denotes the West Texas Intermediate (WTI) crude oil prices (front-month futures), while the right axis denotes the implied volatilities of at the money (ATM) options. 
The period analyzed was characterized by considerable changes in both oil prices and option volatility. In the first stage, WTI crude oil prices were trending in an upward channel formation (2009-2011), and then they ranged between \$80-110 USD per barrel for over three years (until October 2014). Large declines were recorded at the end of 2014 (as a result of Organization of the Petroleum Exporting Countries (OPEC) decision not to limit production), and the downward trend continued until early 2016. In the following months, prices rebounded but failed to return to $\$ 80$ USD per barrel. The spread of COVID-19 in the first part of 2020 contributed to further declines in many economic branches. These resulted in a sharp drop in global oil consumption.

Taking into account the criterion of implied volatility of ATM options, the analyzed period was divided into five categories:

- 0-20 implied volatility of ATM options was below the 20th percentile of the analyzed period;

- 20-80 implied volatility of ATM options was between the 20th and 80th percentile;

- 80-90 implied volatility of ATM was higher than $80 \%$ and not greater than $90 \%$ of the volatility observed;

- $\quad 90-95$ implied volatility of ATM options was higher than $90 \%$, and not greater than $95 \%$ of the volatility observed;

- 95-100 implied volatility of ATM options was above the 95th percentile.

When creating the volatility categories, the frequency of each volatility level and the differences between the maximum and minimum values in the individual groups were considered. In the first step, the data were divided into five groups, i.e., $0-20,20-40,40-60,60-80$, and $80-100$. Following that, we noticed that the differences in the levels of implied volatility between the groups 20-40 and 40-60 or 40-60 and 60-80 are not significant, so they should not have a large impact on, e.g., the level of strategy costs in these categories. That is why, as the next step, we have chosen the categories 0-20, $20-80$, and $80-100$. However, the last category contained observations with implied volatility ranging from $47 \%$ to $190 \%$. For this reason, considering the $80-100$ as one range, could cause failure to find the relations that may be important in further analyses and then to apply an appropriate type of option strategy. Therefore, the implied volatility rated above the 80th percentile was divided into three subcategories, i.e., 80-90, 90-95, and 95-100. As a result, five implied volatility categories were obtained: 0-20, 20-80, 80-90, 90-95, and 95-100. Descriptive statistics for each of the categories are given in Table 2.

Table 2. Descriptive statistics of implied volatility for ATM options.

\begin{tabular}{cccccc}
\hline Category of Implied Volatility & $\mathbf{0 - 2 0}$ & $\mathbf{2 0 - 8 0}$ & $\mathbf{8 0 - 9 0}$ & $\mathbf{9 0 - 9 5}$ & $\mathbf{9 5 - 1 0 0}$ \\
\hline Number of obs. & 573 & 1724 & $\mathbf{2 8 6}$ & 144 & 144 \\
Mean & $19.38 \%$ & $31.81 \%$ & $47.23 \%$ & $59.03 \%$ & $99.48 \%$ \\
Median & $19.72 \%$ & $30.78 \%$ & $46.84 \%$ & $58.35 \%$ & $87.85 \%$ \\
Min & $11.68 \%$ & $23.64 \%$ & $43.44 \%$ & $52.91 \%$ & $68.20 \%$ \\
Max & $23.62 \%$ & $43.40 \%$ & $52.90 \%$ & $68.11 \%$ & $187.86 \%$ \\
Standard deviation & $2.87 \%$ & $5.44 \%$ & $2.53 \%$ & $4.34 \%$ & $30.61 \%$ \\
Skewness & -0.42 & 0.45 & 0.47 & 0.31 & 1.3 \\
Kurtosis & -0.79 & -0.89 & -0.79 & -1.11 & 0.64 \\
JB & 359.79 & 1145.17 & 181.70 & 103.66 & 73.98 \\
\hline
\end{tabular}

Notes: the sample period was from 17 November 2008 to 15 April 2020; JB represents the Jarque-Bera test statistics for normality.

According to the analyses, the highest spread in the implied volatility values of ATM options can be observed in the 95-100 category. The examined indicator remained lower than $68.2 \%$ for $95 \%$ of the time. The implied volatility that exceeded this level occurred in 144 out of 2871 observations. The observations were concentrated in two time intervals, i.e., at the beginning and at the end of the analyzed period. The first stage of high volatility, including WTI Crude Oil option contracts with delivery occurred in January, February, March, April, and May in 2009. This period coincided with the 
financial crisis that spilled over to the commodity markets and resulted in a sharp drop in oil prices in the second half of 2008. A very high implied volatility of ATM options also occurred in four days of 2015 , considering options with an exercise date within one or two days so the higher level of volatility was also related to the upcoming exercise date (the increase in implied volatility is quite commonly observed in the last days of option life). A high level of volatility also occurred at the beginning of 2016 (February: nine cases), once in 2018, and once in 2019. More extended period of the high level of implied volatility (category 95-100) began in March 2020 and continued until completing the analyzes discussed in this study (options with delivery for May 2020, expiry date: 16 April).

For each ATM option, we calculated the difference between the strike price and the price of the underlying asset (WTI crude oil price) at the expiration date. The distributions of oil price changes in each volatility category are presented in Figure 3.

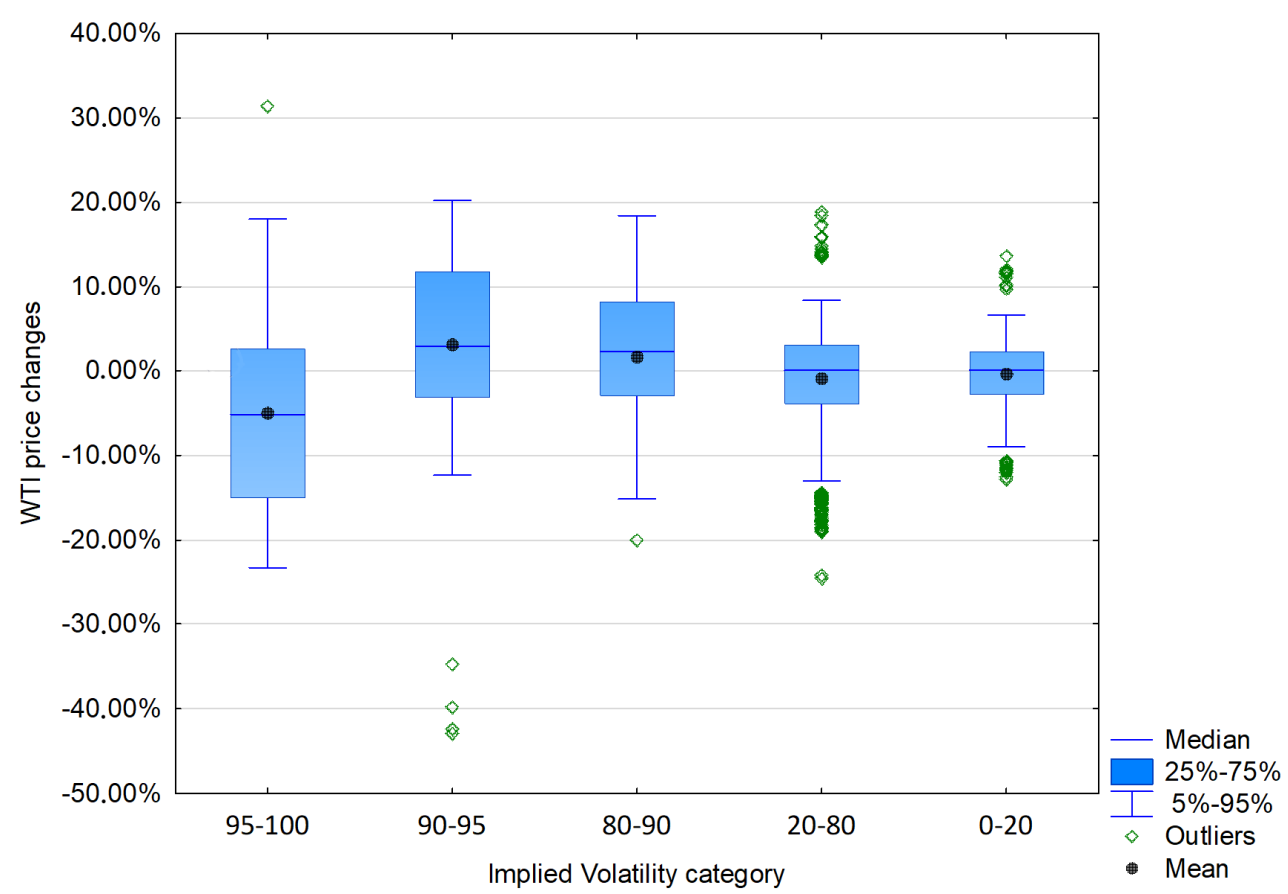

Figure 3. Box-and-whisker plot for the WTI crude oil price changes in five categories of implied volatility from 17 November 2008 to 15 April 2020.

The box-and-whisker plot shows that the level of oil price changes during the period of the option activity was by far the highest, with high levels of implied volatility (categories: 80-90, 90-95, and 95-100). In the 0-20 category, WTI crude oil price changes did not exceed $3 \%$ in $75 \%$ of cases and $4 \%$ for the 20-80 category. For the remaining three categories, the differences between the upper and lower quartile were much greater. What is more, with high levels of volatility, it can also be seen that both the median and the mean differed significantly from 0 . For the categories 80-90 and 90-95, the price increases prevailed with the price declines for the category 95-100. There is also an increase in deviations from the mean, along with an increase in implied volatility. For the categories $0-20$ and 20-80 the standard deviation is $4.5 \%$ and $6.9 \%$, respectively, while for the categories $80-90,90-95$, and $95-100$ it is $10.8 \%, 12.2 \%$, and $12.6 \%$, respectively.

In order to enable the construction of the selected vertical spreads, it was also necessary to determine the value of option premiums for options with strike price not equal to the ATM strike price. Using data from NYMEX and the Black formula [34], seven options with different strike prices and identical exercise dates were valued for each day of quotation. Again, the analysis focused on the WTI crude oil European options. However, it was agreed that these would be the options with an exercise date longer than 10 days (it varied between 11 and 34 days). These were the options: 
(O1) with strike price \$2 USD lower than the ATM strike price;

(O2) with strike price \$1 USD lower than the ATM strike price;

(O3) with strike price \$0.5 USD lower than the ATM strike price;

(O4) ATM options whose strike price was closest to the WTI crude oil price in the date of opening the position;

(O5) with strike price \$0.5 USD higher than the ATM strike price;

(O6) with strike price \$1 USD higher than the ATM strike price;

(O7) with strike price \$2 USD higher than the ATM strike price.

The descriptive statistics for the changes of the WTI crude oil prices (with time expiration between 11 and 34 days) in five categories of implied volatility are presented in Table 3 and Figure 4.

Table 3. Descriptive statistics of WTI crude oil price changes for five categories of implied volatility.

\begin{tabular}{cccccc}
\hline Category of Implied Volatility & $\mathbf{0 - 2 0}$ & $\mathbf{2 0 - 8 0}$ & $\mathbf{8 0 - 9 0}$ & $\mathbf{9 0 - 9 5}$ & $\mathbf{9 5 - 1 0 0}$ \\
\hline Number of obs. & 393 & 1158 & 179 & 91 & 86 \\
Mean & $-0.61 \%$ & $-1.21 \%$ & $2.04 \%$ & $4.14 \%$ & $-6.21 \%$ \\
Median & $-0.19 \%$ & $0.01 \%$ & $4.59 \%$ & $8.96 \%$ & $-7.52 \%$ \\
Min & $-12.81 \%$ & $-49.98 \%$ & $-45.99 \%$ & $-42.88 \%$ & $-29.89 \%$ \\
Max & $13.65 \%$ & $18.89 \%$ & $24.56 \%$ & $25.49 \%$ & $31.41 \%$ \\
Standard deviation & $5.16 \%$ & $7.98 \%$ & $13.01 \%$ & $14,92 \%$ & $14.16 \%$ \\
Skewness & -0.02 & -1.45 & -1.00 & -1.38 & 0.85 \\
Kurtosis & -0.18 & 5.91 & 1.65 & 2.23 & 0.09 \\
JB & 165.83 & 815.24 & 43.43 & 31.03 & 40.85 \\
\hline \% of days with price falls & 51.40 & 50.00 & 34.08 & 37.36 & 74.42 \\
\hline \% of days with price increases & 48.60 & 50.00 & 65.92 & 62.64 & 25.58 \\
\hline
\end{tabular}

Notes: The number of days to maturity for the options was longer than 10 days but no longer than 34 days; JB represents the Jarque-Bera test statistics for normality.

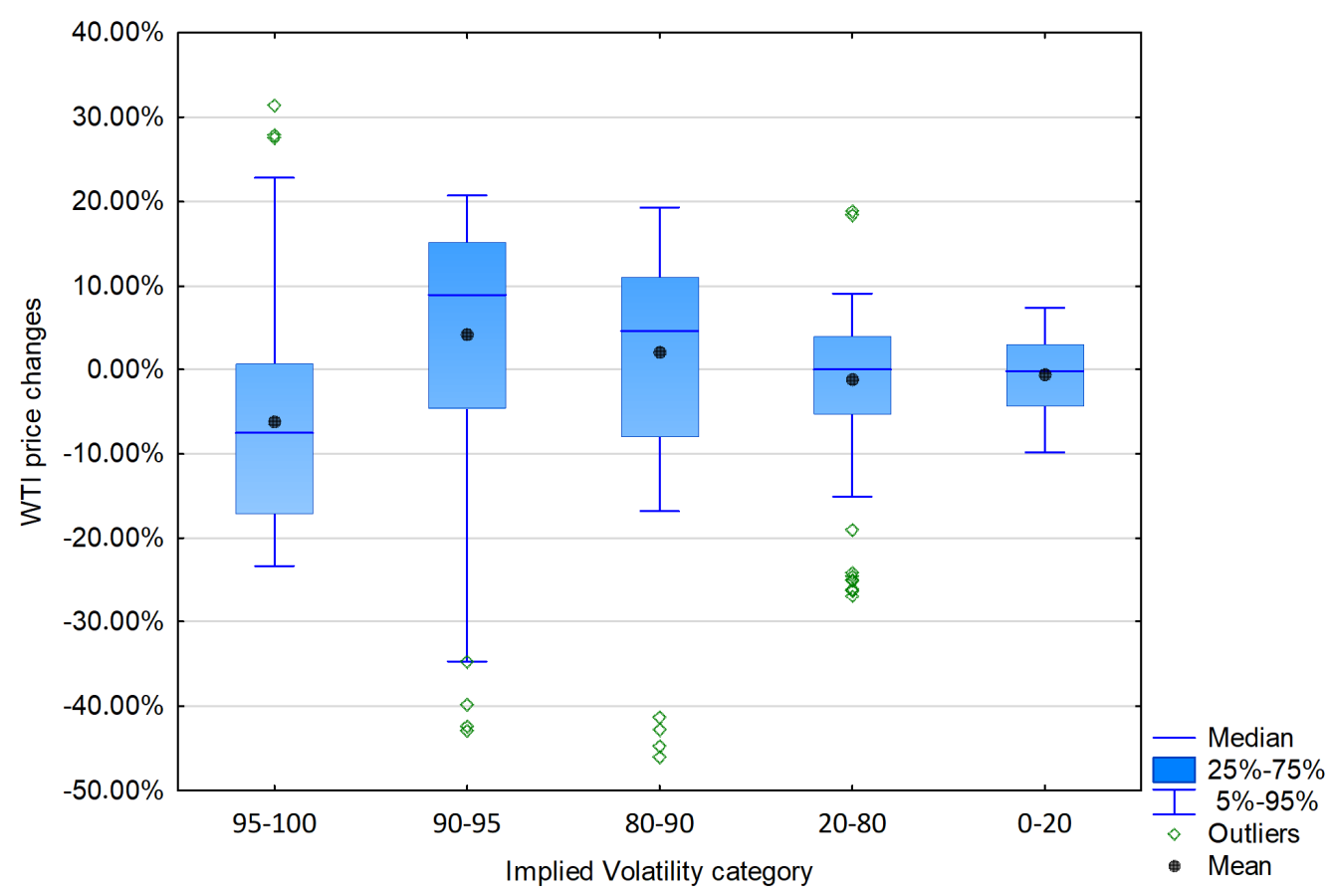

Figure 4. Box-and-whisker plot for the WTI crude oil price changes in five categories of implied volatility with the time to expiration for 11 to 34 days. 
Although some of the observations were eliminated from further analysis, we can still see that, with increasing volatility levels, the absolute value of medians and average changes in oil prices in the analyzed period increased. The skewness values suggest that only in 95-100 category, the oil price changes have positively skewed distributions. In categories 0-20 and 95-100, the distributions were mesokurtic, while in other categories, they were leptokurtic. The Jorque-Bera statistics give evidence of the non-normality of the oil price changes distributions for each implied volatility category.

The presented statistics also show a prevailing downward trend in the category with the highest level of implied volatility (95-100). For almost $75 \%$ of cases in this category, the oil price on the date of opening a position in the options was lower than the price on the expiry date. Such a large number of days with declines suggests that for the volatility category 95-100 bear strategies should provide the best results. In turn, the categories 80-90 and 90-95 were dominated by upward trends. Considering the level of implied volatility, this favors strategies that protect against price increases.

\section{Results and Discussion}

The obtained results for each variant of the vertical spreads refer to the five categories of implied volatility. For the bull call, bull put, bear call, and bear put strategies, three variants were considered for each, and for the bull put ladder and bear call ladder strategies, one variant for each. Each variant was created by using certain combinations of options (O1)-(O7), which take into account the specificity of the particular strategy. As a result, 14 strategy variants were obtained (the difference between the strike price of the option, and the strike price of the ATM option as of the date of opening the position is indicated in brackets):

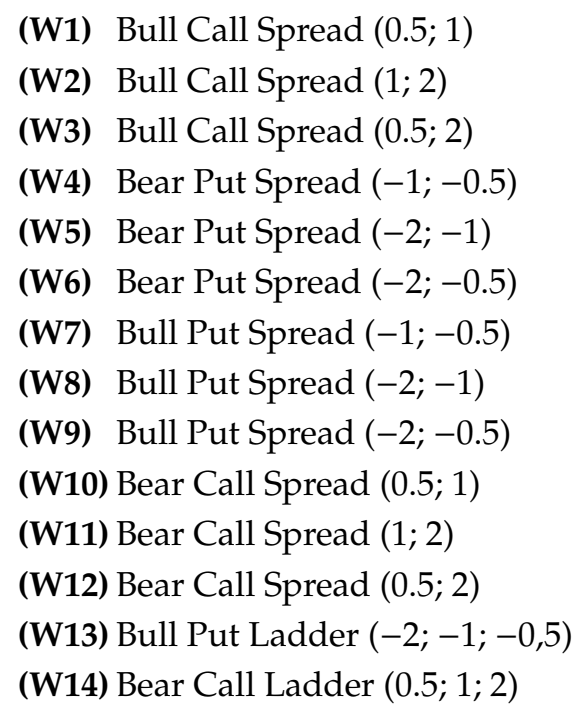

The obtained results were divided into three parts. The first one analyzes the impact of implied volatility on the costs and break-even points (BEPs) of the strategy. In this case, the costs are interpreted as the maximum loss that could have been incurred in a given variant of the strategy (which is not necessarily equal to the purchase cost of that particular strategy). The second and third parts focus on the analysis of the final results obtained in each strategy variant in five categories of volatility. These analyses reveal both the frequency of the execution of the strategy with a profit or loss (Section 4.2) and the outcomes at different levels of WTI oil price changes (Section 4.3). The costs and the final results were determined in USD, concerning the size of the WTI crude oil option contract. According to the NYMEX standards, the basic unit in such a contract is 1000 barrels of oil. Two option contracts were used in the construction of the variants (W1)-(W12), while variants (W13) and (W14) required the use of three options with different strike prices. 


\subsection{Cost and BEP in Vertical Spread Strategy}

The calculations showed that the level of implied volatility has a particularly high impact on the cost (maximum loss) in the bull put ladder (W13) and bear call ladder (W14) strategies. These strategies are the most expensive in the group of Vertical spreads. This is the consequence of the use of two long positions and only one short position in options (in contrast to the other analyzed strategies where one long and one short position are used in each of them). It can be observed, however, that for the lowest levels of volatility (0-20), the costs differ only slightly from the most expensive variants of the other strategies, i.e., variants (W9) and (W12), and are on average USD 100-150 more expensive (see Appendix A, Table A1). This difference increases, however, with the level of implied volatility. In the 20-80 category, it is $\$ 600-650$ USD; in the 80-90 and 90-95 categories it is approximately $\$ 1000$ USD; and in the 95-100 category, it reaches approximately \$2000 USD. It should also be noted that the bear call ladder strategy is usually slightly more expensive than the bull put ladder (using options with the symmetric strike prices that were analyzed for the purpose of this study). This is due to the shape of the volatility curve defined as a function of the strike price of the options (volatility smile effect [59]).

In each of the four remaining groups of strategies we observed an increase in the cost. It went along with an increase in the difference between the strike prices of the buying and selling option, and with a "moving away" from the strike price of the ATM options. Therefore, the variants with options $(\mathrm{O} 2)$ and $(\mathrm{O} 3)$ are always cheaper than those that use options $(\mathrm{O} 1)$ and $(\mathrm{O} 2)$, and these, in turn, are cheaper than variants with options (O1) and (O3). Similar relations can be observed for the strategy variants designed with the use of options (O5), (O6), or (O7); the cheapest are those with options (O5) and (O6), more expensive are variants with options (O6) and (O7), and the most expensive with options (O5) and (O7). However, in contrast to the bull put ladder and bear call ladder strategies, the rate of cost increase in the bull call spread, bear put spread, bull put spread, and bear call spread strategies is much lower when the level of implied volatility increases. Taking into account the values of the costs (Appendix A, Table A1), it can be noticed that they are practically the same for each category of volatility but this is due to the much higher average oil prices for low volatility $(0-20)$ compared with higher volatility rates (90-95 and 95-100). However, when considering the ratio of the costs of a strategy to the value of one option contract (see Figure 5 and Appendix A, Table A2), it can be seen that limited strategies in the 95-100 category are approximately two times more expensive than the same strategies in the $0-20$ category. This does not change the fact that costs in limited strategies are much less volatile when the level of implied volatility is increased in comparison with unlimited strategies, for which the transition from the 0-20 to the 95-100 category involves a seven-fold increase in costs.

A value closely linked to the level of costs and relevant from the perspective of careful and effective application of the vertical spreads is the BEP. It provides information on the range of prices in which a particular strategy will generate a profit for the trader. For each strategy variant, we established the average values of BEPs with regard to the categories of implied volatility. In order to eliminate different levels of WTI crude oil prices in the analyzed period, this indicator was expressed as a percentage of the value of the ATM strike price on the date of opening a position in the selected variant of strategy. Table 4 contains information on the price ranges in which the strategy made it possible to generate a profit. 


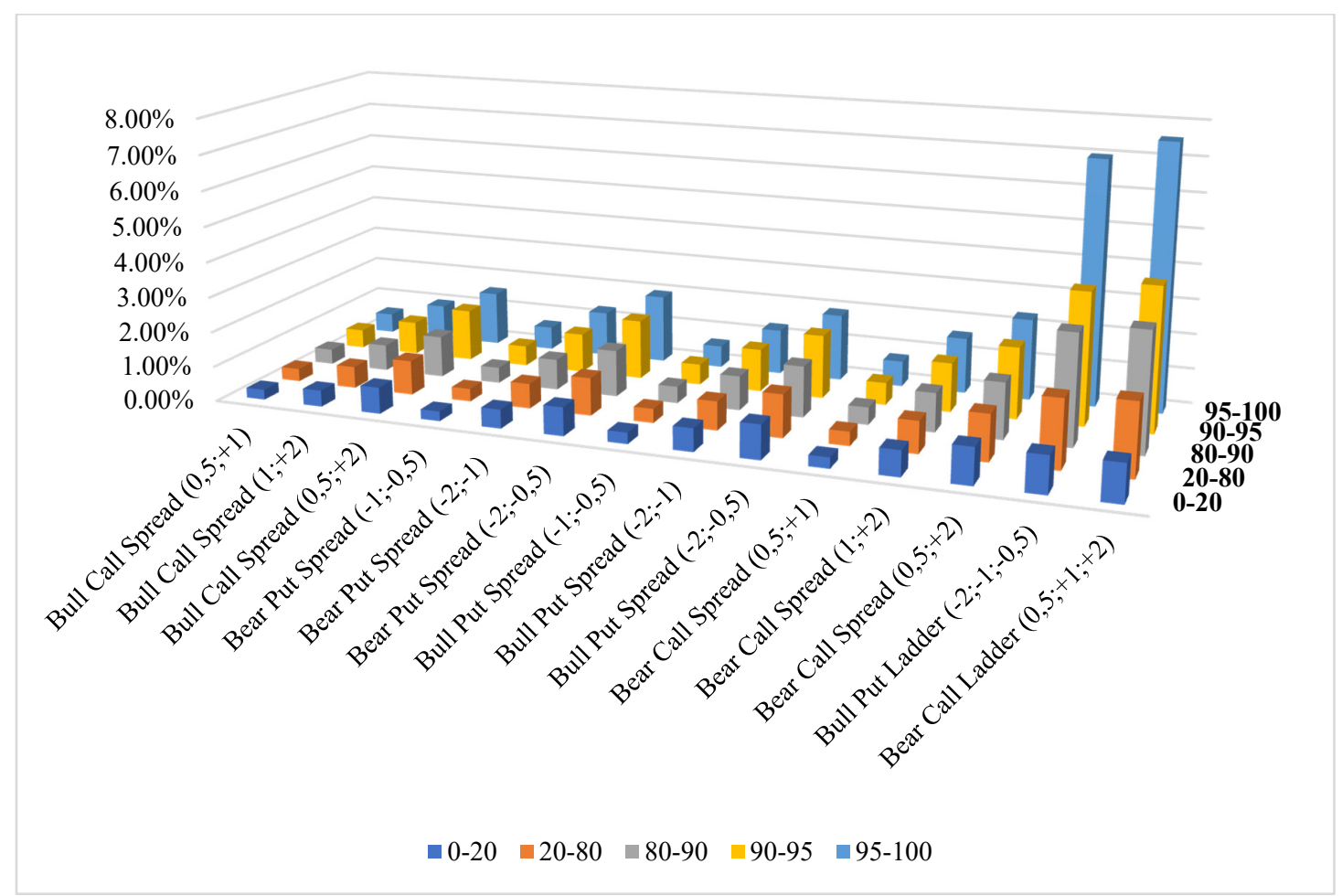

Figure 5. Mean costs for vertical spread option strategies (\% of ATM strike price).

Table 4. Price ranges in which the individual variants of vertical spreads generated a profit.

\begin{tabular}{|c|c|c|c|c|c|c|}
\hline & \multirow{2}{*}{ Variant } & \multicolumn{5}{|c|}{ Category of Implied Volatility } \\
\hline & & $0-20$ & $20-80$ & $80-90$ & 90-95 & 95-100 \\
\hline \multirow{6}{*}{ Net debit spread } & Bull Call Spread $(0.5 ;+1)$ & over $100.88 \%$ & over $101.13 \%$ & over $101.36 \%$ & over $101.71 \%$ & over $101.86 \%$ \\
\hline & Bull Call Spread $(1 ;+2)$ & over $101.65 \%$ & over $102.14 \%$ & over $102.60 \%$ & over $103.30 \%$ & over $103.58 \%$ \\
\hline & Bull Call Spread $(0.5 ;+2)$ & over $101.35 \%$ & over $101.74 \%$ & over $102.11 \%$ & over $102.66 \%$ & over $102.85 \%$ \\
\hline & Bear Put Spread $(-1 ;-0.5)$ & under $99.13 \%$ & under $98.87 \%$ & under $98.62 \%$ & under $98.25 \%$ & under $98.04 \%$ \\
\hline & Bear Put Spread $(-2 ;-1)$ & under $98.27 \%$ & under $97.76 \%$ & under $97.27 \%$ & under $96.52 \%$ & under $96.12 \%$ \\
\hline & Bear Put Spread $(-2 ;-0.5)$ & under $98.60 \%$ & under $98.17 \%$ & under $97.75 \%$ & under $97.12 \%$ & under $96.74 \%$ \\
\hline \multirow{6}{*}{ Net credit spread } & Bull Put Spread $(-1 ;-0.5)$ & over $99.13 \%$ & over $98.87 \%$ & over $98.62 \%$ & over $98.25 \%$ & over $98.04 \%$ \\
\hline & Bull Put Spread $(-2 ;-1)$ & over $98.27 \%$ & over $97.76 \%$ & over $97.27 \%$ & over $96.52 \%$ & over $96.12 \%$ \\
\hline & Bull Put Spread $(-2 ;-0.5)$ & over $98.60 \%$ & over $98.17 \%$ & over $97.75 \%$ & over $97.12 \%$ & over $96.74 \%$ \\
\hline & Bear Call Spread $(0.5 ;+1)$ & under $100.88 \%$ & under $101.13 \%$ & under $101.36 \%$ & under $101.71 \%$ & under $101.86 \%$ \\
\hline & Bear Call Spread $(1 ;+2)$ & under $101.65 \%$ & under $102.14 \%$ & under $102.60 \%$ & under $103.30 \%$ & under $103.58 \%$ \\
\hline & Bear Call Spread $(0.5 ;+2)$ & under $101.35 \%$ & under $101.74 \%$ & under $102.11 \%$ & under $102.66 \%$ & under $102.85 \%$ \\
\hline \multirow{2}{*}{ Unlimite } & Bull Put Ladder $(-2 ;-1 ;-0.5)$ & under $96.57 \%$ & under $95.01 \%$ & under $93.16 \%$ & under $91.54 \%$ & under $87.84 \%$ \\
\hline & Bear Call Ladder $(0.5 ;+1 ;+2)$ & over $104.65 \%$ & over $106.64 \%$ & over $108.95 \%$ & over $111.13 \%$ & over $115.33 \%$ \\
\hline
\end{tabular}

Note: the end of the range is the mean value of the break-even point (BEP) for each volatility category, expressed as a percent of the ATM option strike price.

The presented values show that the net credit spread strategies (bear call spread and bull put spread) generated the profits in the widest price ranges. What is more, the increase in implied volatility made these ranges even wider. This is undoubtedly an advantage of these strategies, but when compared with net debit spread strategies (bear put spread and bull call spread), they turn out to be more expensive with lower maximum profit. In the case of net debit spread and unlimited strategies, the higher level of implied volatility results in a narrowing of the price ranges in which the strategy generated profit. This is particularly noticeable in the case of unlimited strategies. The bull put ladder strategy in the $0-20$ category generated profit with a price drop of at least $3.5 \%$ relative to the oil price as of the date of taking a position in this strategy. In the 95-100 category, on the contrary, the necessary 
decline had to be over $12 \%$. Even greater price movements made it possible for profits to be generated in the bear call ladder strategy where in the 0-20 category price increases of more than $4.5 \%$ had to be expected, but in the 95-100 category, the increase had to exceed $15 \%$.

\subsection{Analysis the Frequency of Execution the Strategies with Profits and Loss}

In this subsection we analyze the frequency of occurrence of the three different states related to the above-mentioned strategies. The first one concerns the state when the variant of strategy generates a profit, the second: a loss but less than the cost (maximum loss) and the last one: the maximum loss (cost) of the strategy (discussed in Section 4.1). Each of the results was assigned to certain category of implied volatility. The results are presented in Table 5.

Table 5. The frequency of occurrence of the three different states related to the using strategies.

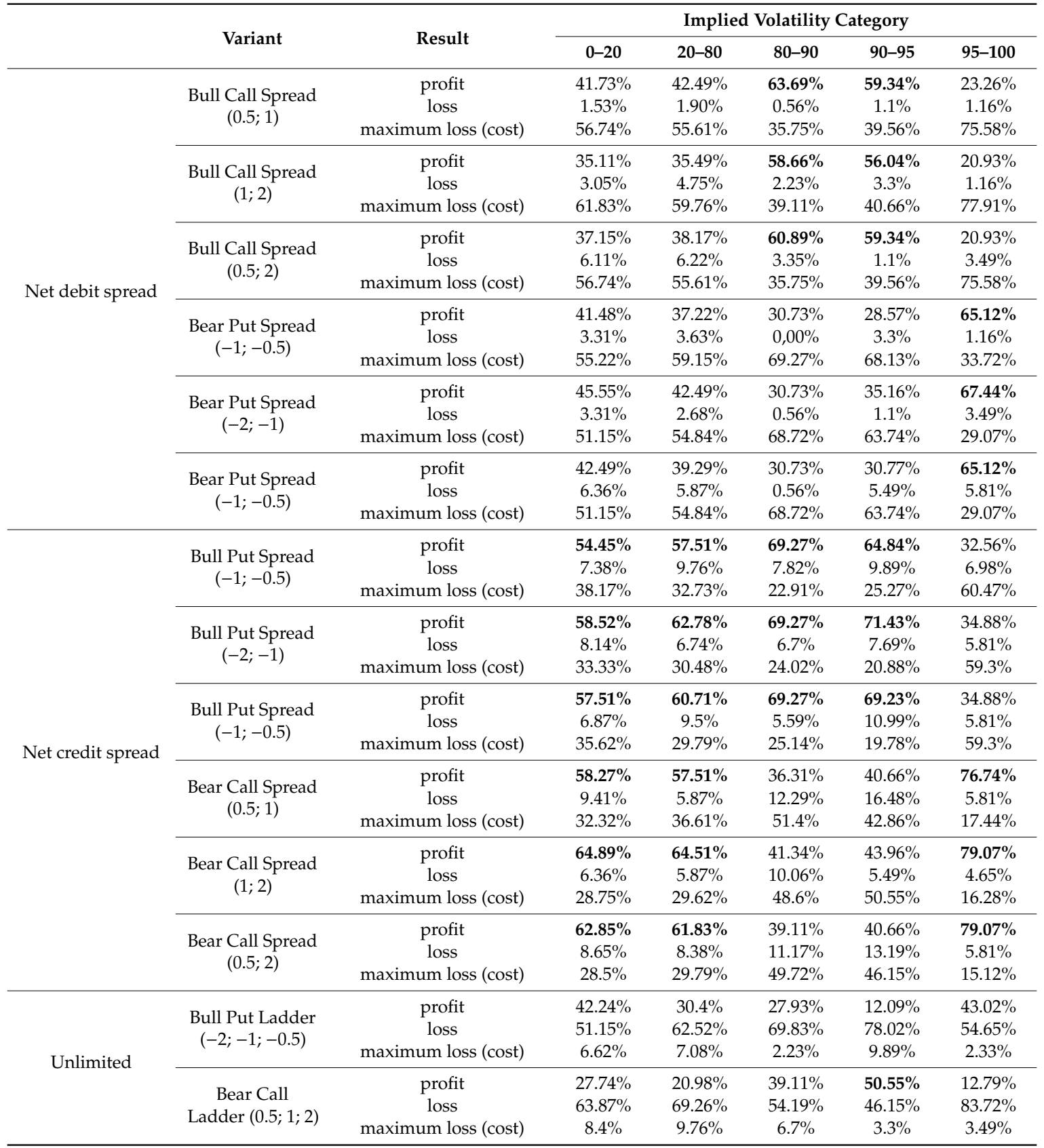

Note: the cells in which the strategy variant was applied with a profit in more than $50 \%$ were in bold. 
The information presented in Table 5 is, of course, strongly linked with the price trends that occurred in the individual categories of implied volatility. However, such an analysis gives a general overview of how the implied volatility changes affect the final results of the particular variant of Vertical spreads. Table 5 also distinguishes those cells in which the strategy variant analysis was applied with a profit in more than $50 \%$ of cases in a particular category. The outcomes show that limited strategies were applied with a profit much more often than unlimited strategies. As can be seen, for only one of the categories (90-95) the bear call ladder strategy was successful in more than half of the cases. Interestingly, the bull put ladder strategy in the volatility category 95-100 was profitable only in $43 \%$ of cases, despite a clear downward trend ( $75 \%$ of observations with price drops). This fact is a consequence of a large increase in costs in the unlimited strategy for this category compared to the other categories of implied volatility. On the other hand, in each category of volatility, there are two limited strategies in which all variants generated profits on more than $50 \%$ of observations. In categories $0-20$ and $20-80$, the strategies that were most often realized with profit were net credit spreads.

\subsection{Strategies Final Results for Different Levels of Oil Price Changes}

The outcomes obtained in the 14 variants of the vertical spreads were also classified according to the level of WTI crude oil price changes. Eight change ranges were considered, and the results were expressed as \% of the value of one option contract (1000 barrels * price of one barrel of oil in USD) on the date of opening a position in the strategy. The means of these values for all strategy variants (referred to as rates of return) are included in Appendix B (Tables A3 and A4). Moreover, the obtained results of strategies were compared on figures. Figures 6-9 refer to the oil prices decreases, while Figures 10-13 to the oil prices increases. Following that, we obtained information on which the strategies can provide profits at each level of change with regard to the category of the implied volatility of options. Also, it is noticeable that the biggest price movements (decreases or increases above $20 \%$ ) were not recorded in the lowest volatility categories. This fact confirms our previous analyses in which we noted that the level of the implied volatility of options as of the date of the creating the strategy, provides important information about the level of future oil price changes.

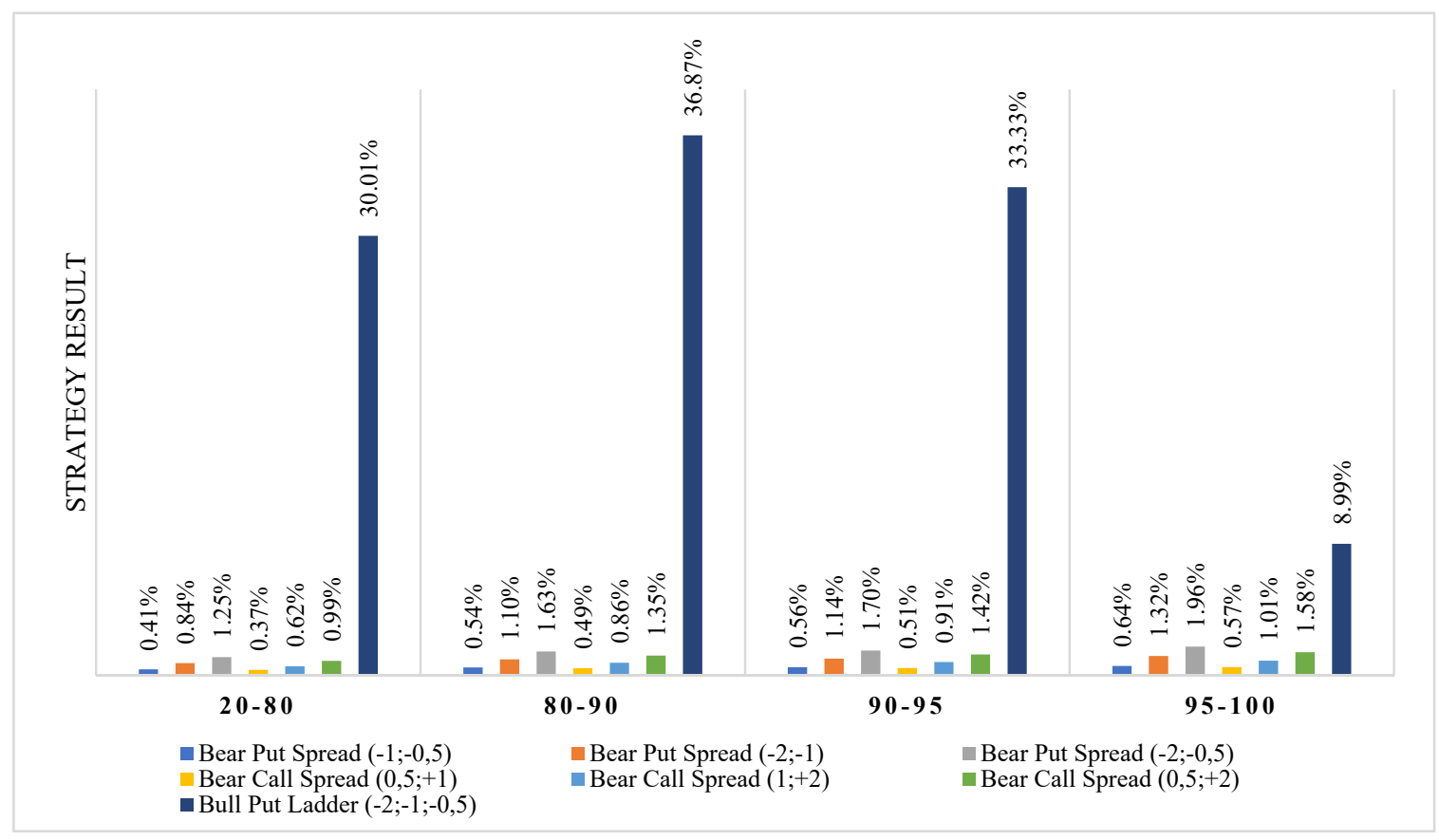

Figure 6. Bear put spread, bear call spread, and bull put ladder results for declines of WTI oil prices exceeding $20 \%$. 


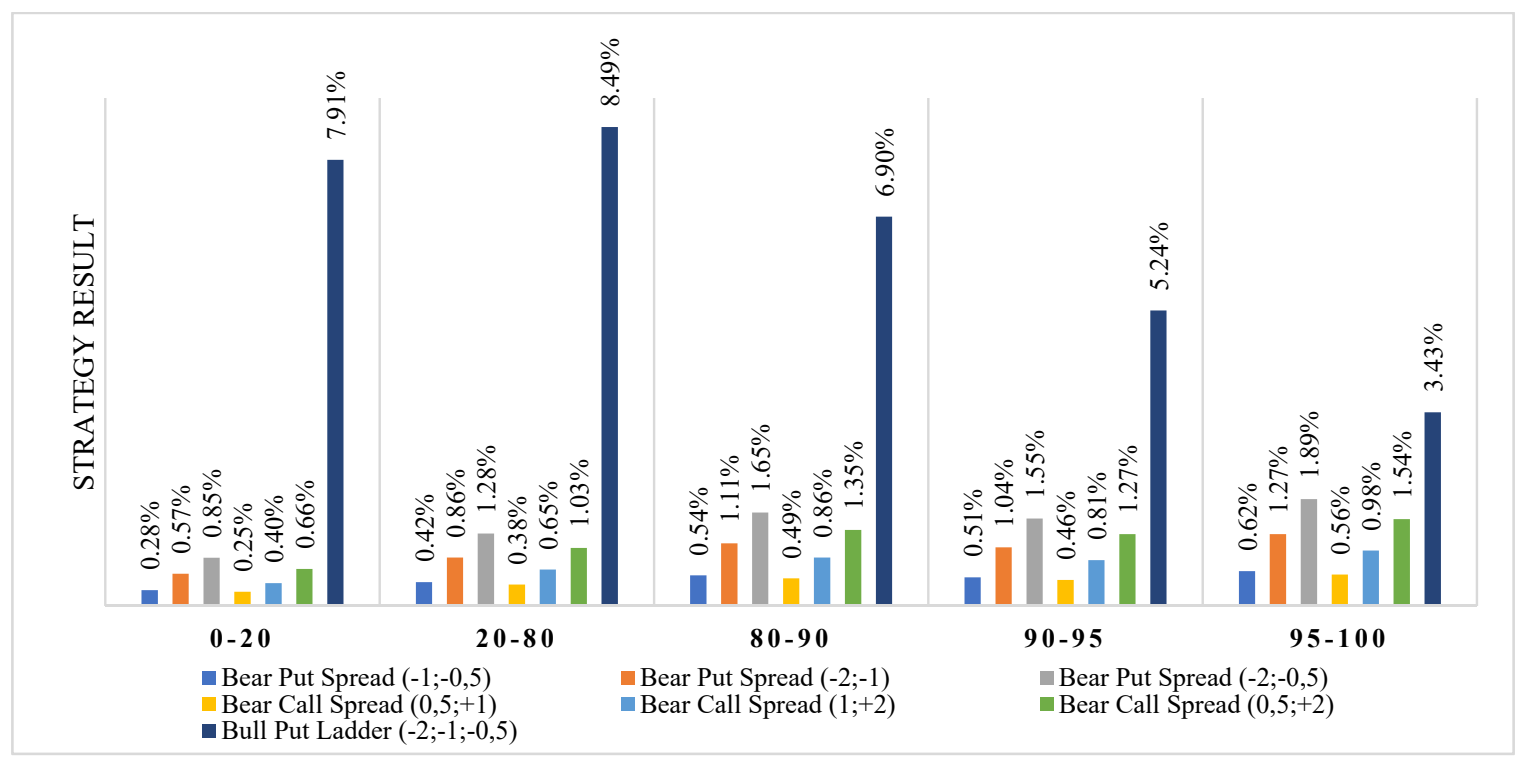

Figure 7. Bear put spread, bear call spread, and bull put ladder results for declines of WTI Crude Oil prices ranging from $10 \%$ to $20 \%$.

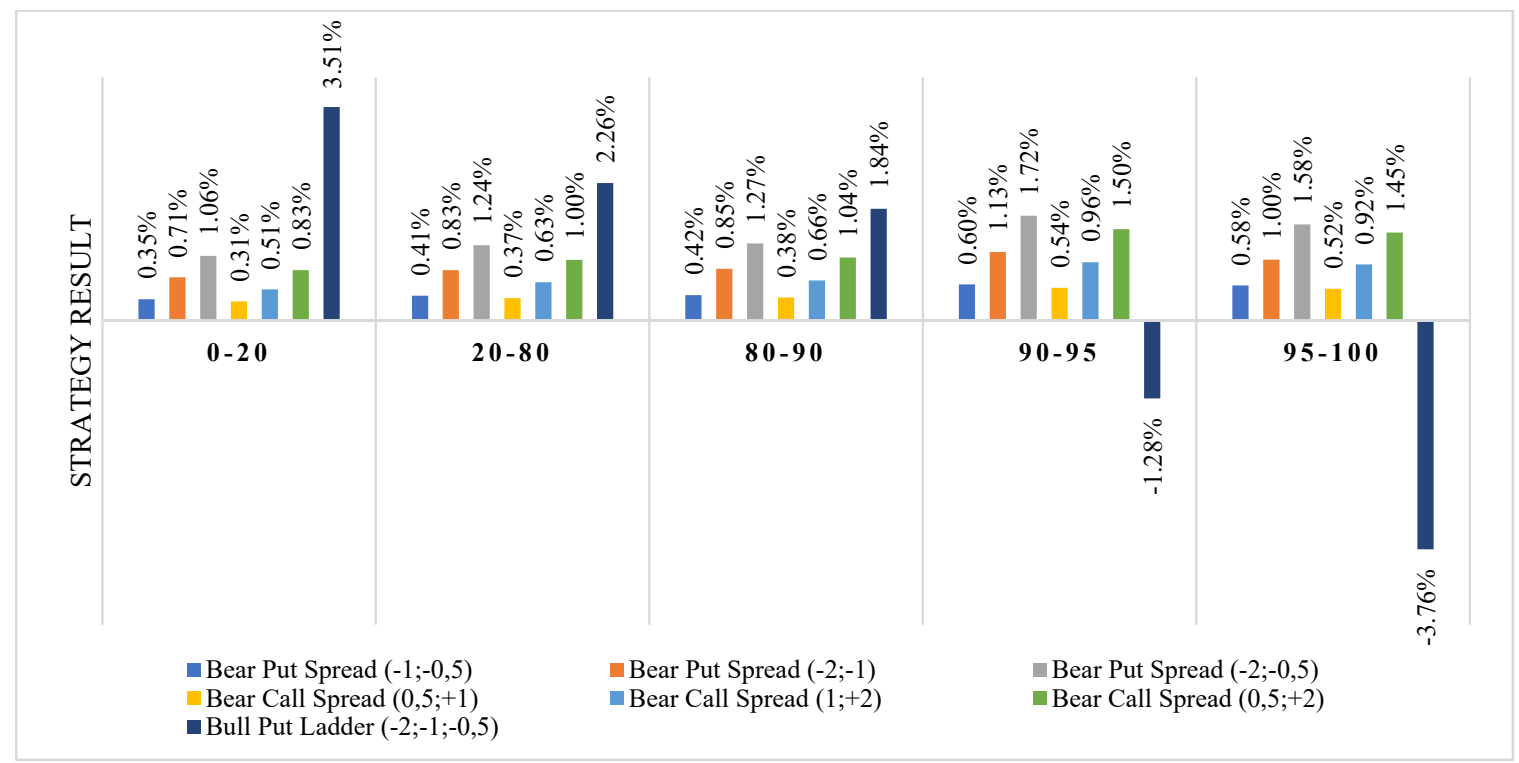

Figure 8. Bear put spread, bear call spread, and bull put ladder results for declines of WTI crude oil prices ranging from $5 \%$ to $10 \%$.

Considering the biggest price drops (in the range $(-\infty ;-20 \%)$ ), by far the highest rates of return could be obtained with the Bull Put Ladder strategy. For the 20-80, 80-90, and 90-95 categories, these values ranged between $30 \%$ and $36 \%$. Such high rates of return were the consequence of sharp falls in oil prices which repeatedly exceeded $35 \%$ (the highest average drops were recorded in the 80-90 category - the highest rate of return for this level of implied volatility). However, a large drop in the rate of return to below $10 \%$ in the $95-100$ category was visible. This was the consequence of a significant increase in the cost of the bull put ladder strategy in comparison with other categories (see Figure 5). 


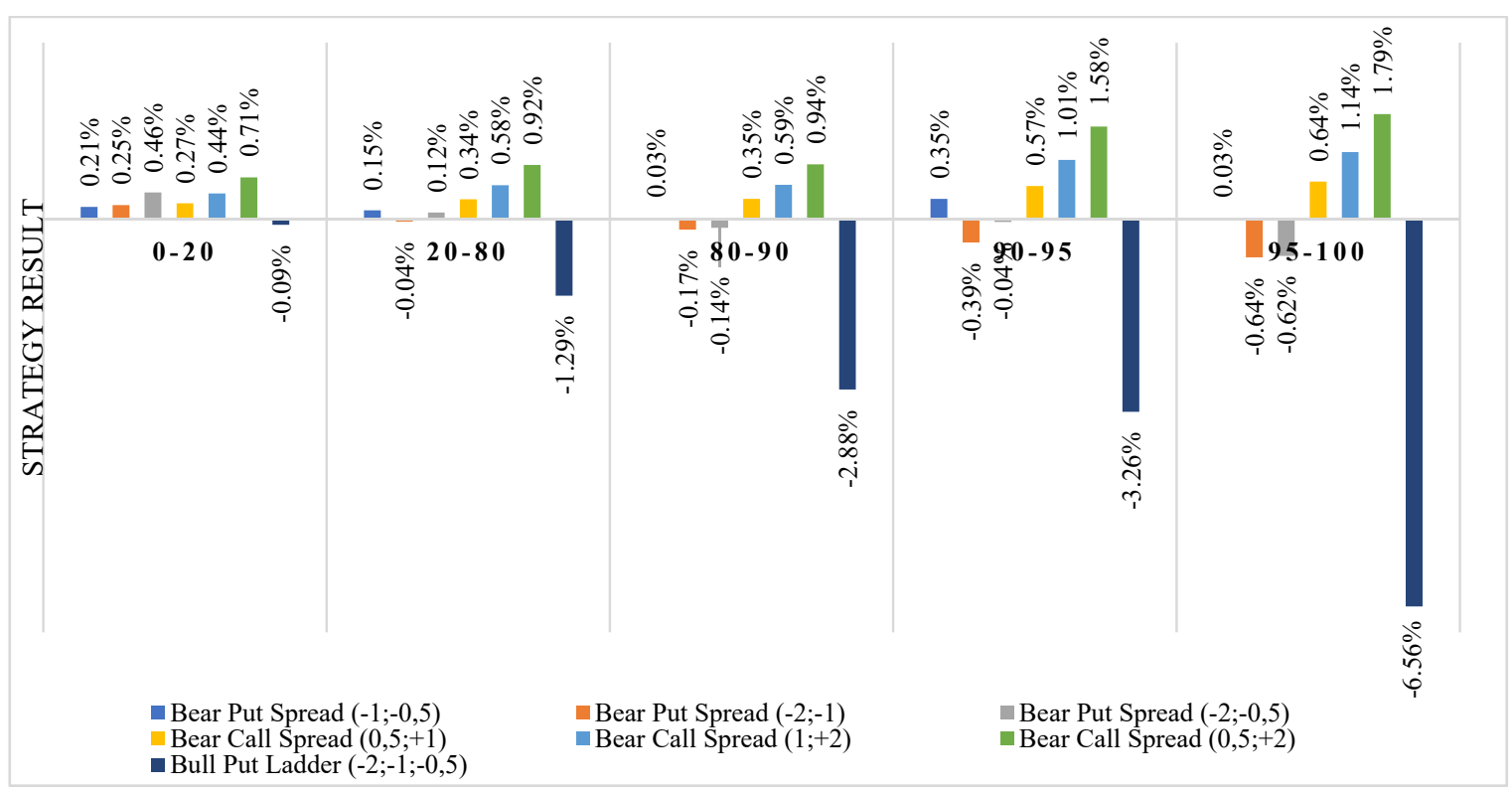

Figure 9. Bear put spread, bear call spread, and bull put ladder results for declines of WTI crude oil prices ranging from $0 \%$ to $5 \%$.

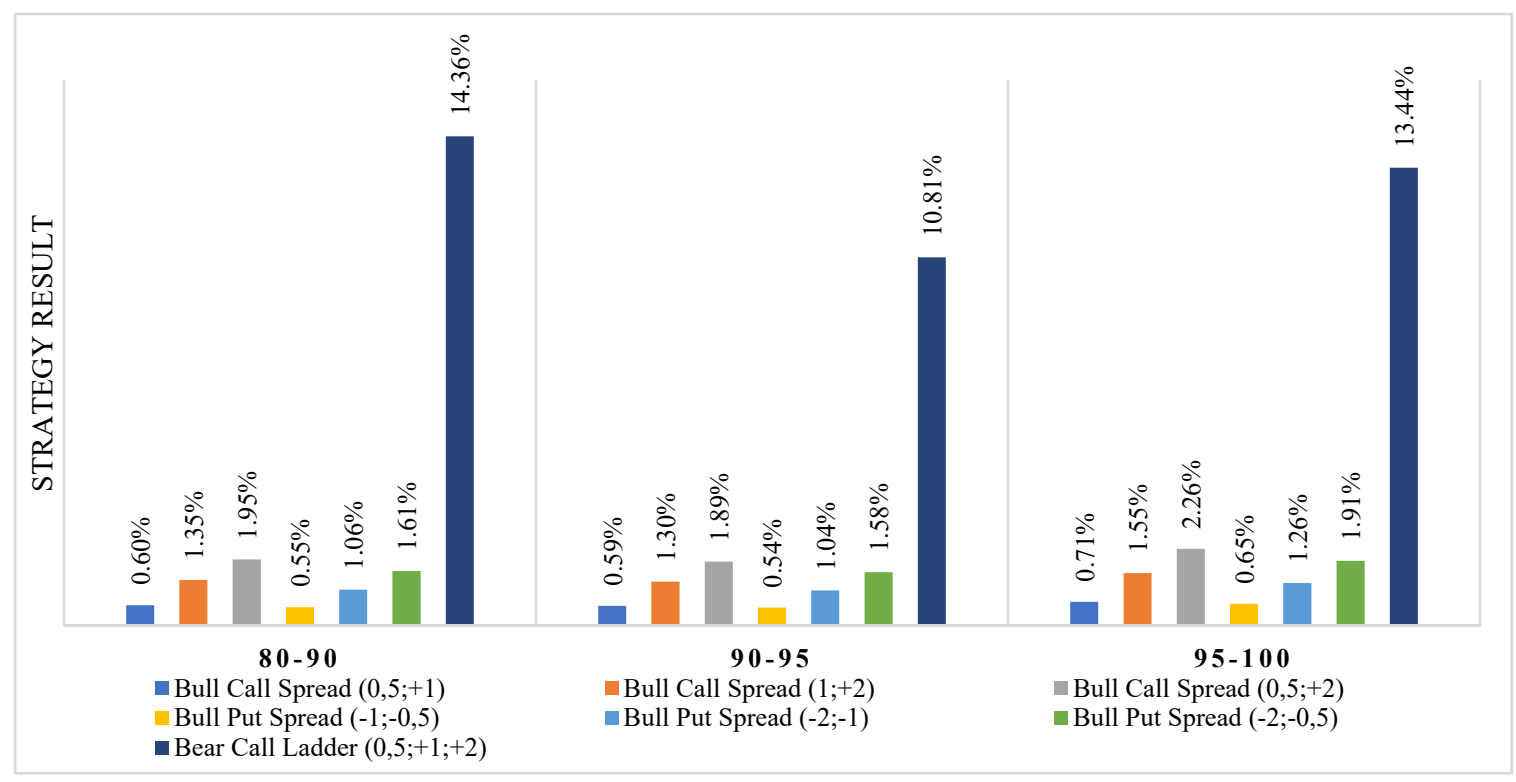

Figure 10. Bull Put Spread, Bull Call Spread and Bear Call Ladder results for increases of WTI Crude Oil prices exceeding $20 \%$.

The analyzed bull put ladder strategy allowed for significantly higher rates of return (compared with other strategies), also with oil price drops of $10-20 \%$. Also, in this range of changes, as a result of a significant increase in costs, the rates of return fell from $8 \%$ in the $0-20$ category to approximately $3.5 \%$ in the 95-100 category. The 5-10\% drop in oil prices meant that profits in the bull put ladder amounted to $2-3.5 \%$ below the 90 th percentile of volatility. With greater volatility (categories 90-95 and 95-100), the strategy was no longer profitable, due to insufficiently large price movements in relation to the costs of the strategy. Slight falls in oil prices (less than 5\%) were also unfavorable in terms of the bull put ladder strategy. 


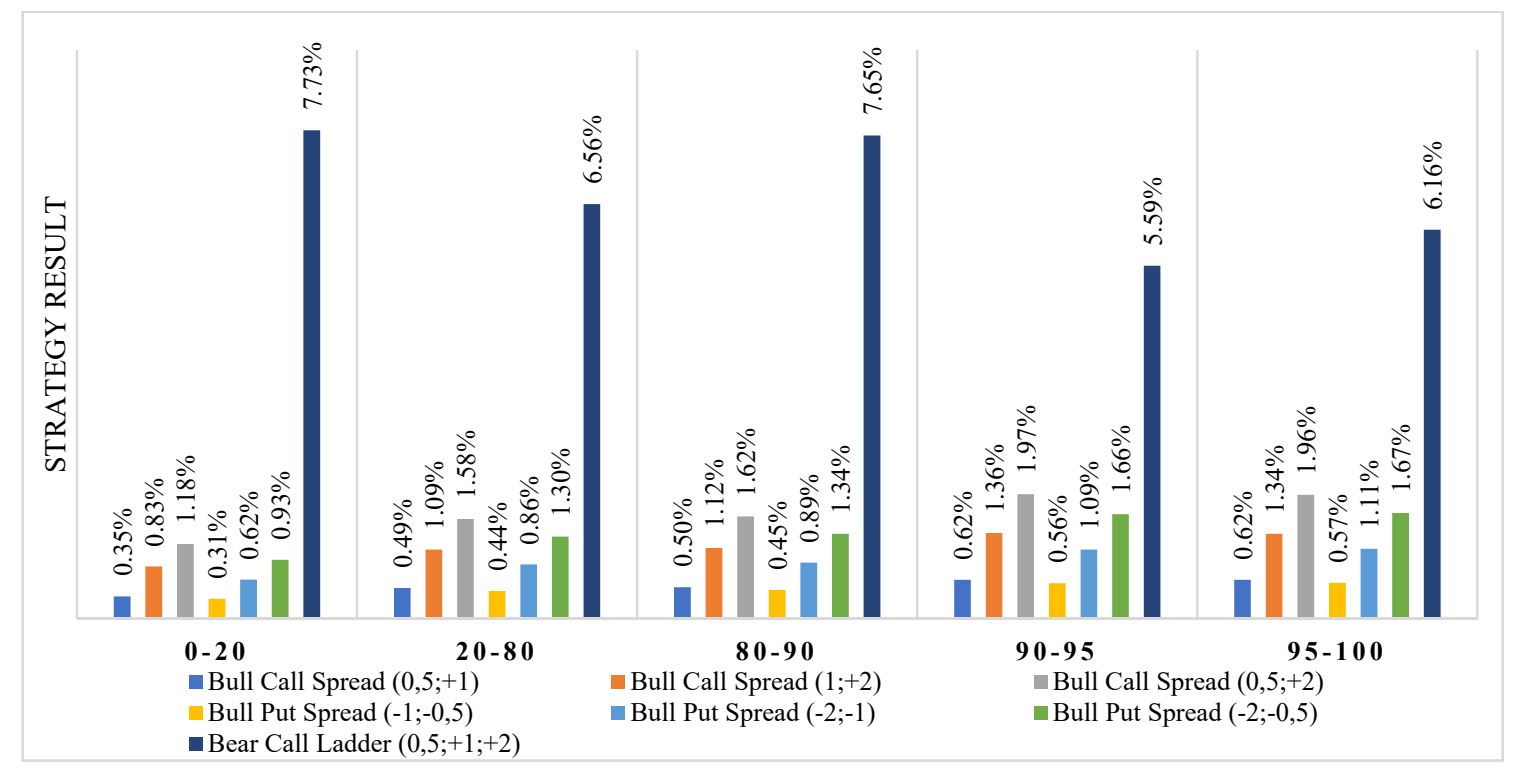

Figure 11. Bull put spread, bull call spread, and bear call ladder results for increases of WTI crude oil prices ranging from $10 \%$ to $20 \%$.

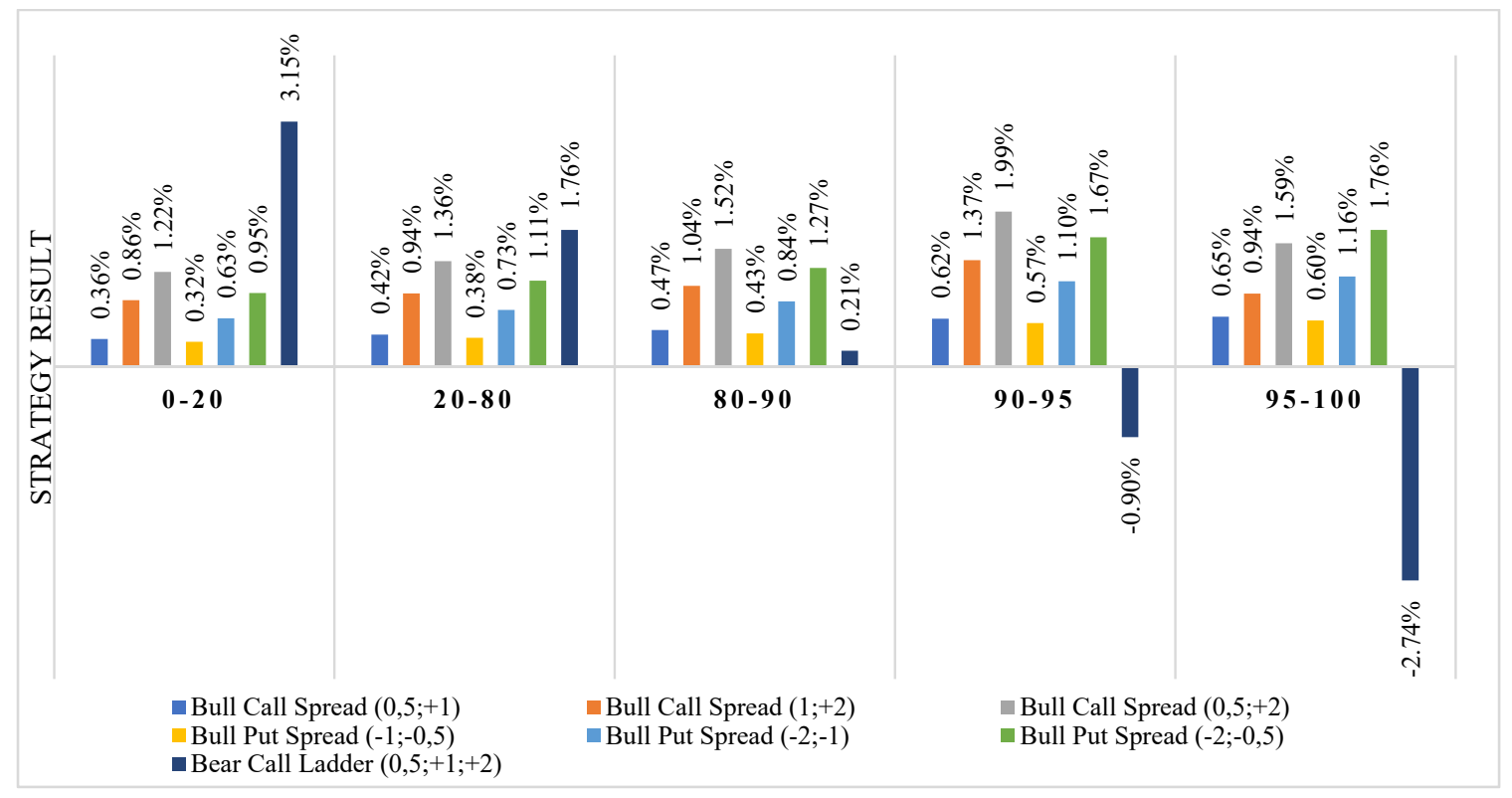

Figure 12. Bull put spread, bull call spread, and bear call ladder results for increases of WTI crude oil prices ranging from $5 \%$ to $10 \%$.

In the case of two limited strategies, i.e., bear call spread and bear put spread, the rates of return observed with price falls were much lower, and their average values did not exceed $2 \%$. The bear put spread strategies allowed for higher rates of return than the bear call spread, with price falls of more than $5 \%$ in each volatility category (see Figures 6-8). With this level of price changes, each of the strategy variants achieved increasingly better results as the implied volatility of options increased. This relation changed with oil price drops not exceeding $5 \%$. Such a level of drops was favorable for the bear call spread strategy, which in the 95-100 category allowed for profits ranging from $0.6 \%$ to $1.8 \%$ on average (the best was the (W12) variant). Average returns for the bear put spread strategy were close to 0 or negative, and increasingly worse as option volatility increased (see Figure 9). 


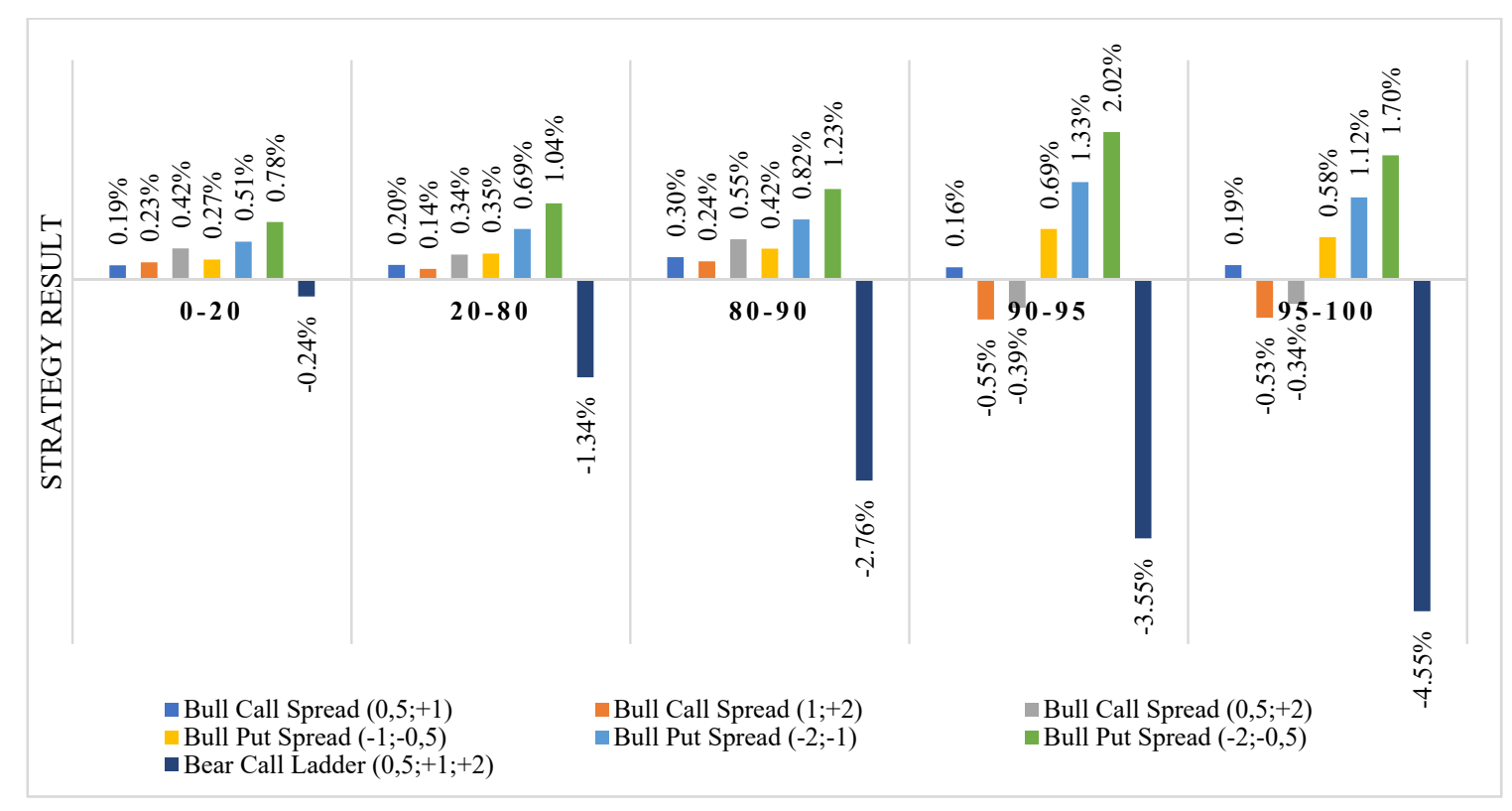

Figure 13. Bull put spread, bull call spread, and bear call ladder results for increases of WTI crude oil prices ranging from $0 \%$ to $5 \%$.

The results obtained with oil price increases in three vertical spread strategies, i.e., bull call spread, bull put spread, and bear call ladder (see Figures 10-13) were quite similar to those obtained with the already discussed strategies amid falling prices. The highest rates of return (11-14\%) with marked increases of WTI crude oil prices (over 20\%) were recorded for unlimited strategy (bear call ladder), while limited strategies (bull call spread and bull put spread) allowed for rates of return no higher than $2 \%$. Smaller price movements and a higher level of implied volatility were unfavorable with regard to the results obtained above all in the bull call ladder strategy. This strategy generated losses for small price increases (below 5\%) regardless of the category of implied volatility. However, the high level of implied volatility had a negative effect on the strategy's final results. Similar to the analysis concerning declines, the most effective strategy for the slightest price increases was the net credit spread strategy (in this case, it was bull put spread). This was the consequence of the fact that net credit spread strategies generated positive rates of return in the widest price range (see Table 4). As a result, small increases in oil prices implied returns of $2 \%$ in the bull put spread strategy and were the highest in the highest categories of implied volatility (90-95 and 95-100).

\section{Conclusions and Future Research Directions}

The purpose of this article was to compare the costs, BEPs, and final results of the vertical spread option strategy at different levels of implied volatility. Guided by the frequency of occurrence of a given volatility level on the WTI crude oil options market, we used five implied volatility categories. The final results obtained in the different options of the strategy were also analyzed in terms of different levels of oil prices changes.

This study has shown that, even with very high levels of implied volatility, the application of the right variants of vertical spreads provides some opportunities to achieve positive rates of return. The most important research findings and our recommendations of using different variants of the Vertical spreads are presented below in four points. 
(1) The costs in the bull put ladder and bear call ladder (unlimited strategies) were very sensitive to the level of implied volatility. The ratio of the costs to the value of the option contract for the highest implied volatility levels (above the 95th percentile) was approximately seven times higher than that for the lowest levels (below the 20th percentile). In the case of unlimited strategies, the cost increase caused by the increase in implied volatility was much slower.

(2) Smaller increases in costs with increasing implied volatility caused that in the categories 80-90, 90-95 and 95-100 the bear put spread, bear call spread, bull call spread, and bull put spread (limited strategies) were realized at a profit much more often than the unlimited strategies. In each category of volatility, there can be found two limited strategies in which all variants were realized with profits in more than $54 \%$ of observations. By comparison, bull put ladder strategies were more likely to lose than profit in each volatility category, whereas the bear call ladder strategy was more than $50 \%$ profitable only in the $90-95$ categories.

(3) The rates of return for unlimited strategies were by far the highest with significant oil price movements (exceeding 10\%). However, due to the higher cost of acquisition (as compared with the limited strategies) of these strategies, it is recommended that they should be used when there are clear signals indicating large price changes. Such signals may include announcements of meetings of representatives of the OPEC + group and their decisions to introduce the production limits (or to deviate from the limits).

(4) For the expected slight changes in prices and a stable situation on the oil market, it is recommended to use net credit spread strategies (bear call in case of price drops and bull put in case of price increases). These strategies generate lower rates of return but protect against oil price fluctuations in the widest price ranges.

The obtained results confirm previous studies, which provided evidence that implied volatility is a parameter that should be taken into account in the process of making decisions regarding both investing and hedging against the risk of price changes [56]. In our opinion, the exploration of the reactions of costs, break-even points and the results of option strategies to the changing market parameters provides an important source of information for entities who regularly use these tools to secure their positions in the oil market. Therefore, in further research, we will focus on other groups of option strategies and the possibilities of using them in the process of managing the risk of oil price changes and other raw materials.

We also plan to use the information value included in the implied volatility (and volatility indices such as VIX) to estimate future rates of return on commodity futures contracts. One of the approaches we plan to use is the rolling window methodology, proposed by Giot [43] and extended by Fassas and Hourvouliades [60], which enables us to examine if extremely high levels of the volatility may signal profitable buying or selling opportunities.

Author Contributions: Conceptualization, B.Ł. and N.I.; model design and model calculations B.Ł.; writing original draft preparation, B.Ł. and N.I.; data visualization, B.Ł.; discussion B.Ł. and N.I.; writing review and editing, B.E. and N.I. All authors have read and agreed to the published version of the manuscript.

Funding: This study was conducted under a research project funded by a statutory grant of the AGH University of Science and Technology in Krakow for maintaining research potential.

Conflicts of Interest: The authors declare no conflict of interest. 


\section{Appendix A. Vertical Spread Option Strategy Costs}

Table A1. Average cost (maximum loss) of vertical spreads for each category of implied volatility (in USD).

\begin{tabular}{cccccc}
\hline & \multicolumn{5}{c}{ Implied Volatility Category } \\
\hline Variant & $\mathbf{0 - 2 0}$ & $\mathbf{2 0 - 8 0}$ & $\mathbf{8 0 - 9 0}$ & $\mathbf{9 0 - 9 5}$ & $\mathbf{9 5 - 1 0 0}$ \\
\hline Bull Call Spread $(0.5 ;+1)$ & 241.71 & 238.04 & 233.62 & 229.71 & 220.54 \\
Bull Call Spread $(1 ;+2)$ & 387.90 & 399.56 & 401.55 & 405.38 & 388.45 \\
Bull Call Spread $(0.5 ;+2)$ & 629.61 & 637.60 & 635.17 & 635.09 & 608.99 \\
Bear Put Spread $(-1 ;-0.5)$ & 230.15 & 236.05 & 241.87 & 246.73 & 255.90 \\
Bear Put Spread $(-2 ;-1)$ & 449.25 & 462.94 & 473.31 & 480.23 & 498.06 \\
Bear Put Spread $(-2 ;-0.5)$ & 679.41 & 698.99 & 715.18 & 726.96 & 753.96 \\
Bull Put Spread $(-1 ;-0.5)$ & 269.85 & 263.95 & 258.13 & 253.27 & 244.10 \\
Bull Put Spread $(-2 ;-1)$ & 550.75 & 537.06 & 526.69 & 519.77 & 501.94 \\
Bull Put Spread $(-2 ;-0.5)$ & 820.59 & 801.01 & 784.82 & 773.04 & 746.04 \\
Bear Call Spread $(0.5 ;+1)$ & 258.29 & 261.96 & 266.38 & 270.29 & 279.46 \\
Bear Call Spread $(1 ;+2)$ & 612.10 & 600.44 & 598.45 & 594.62 & 611.55 \\
Bear Call Spread $(0.5 ;+2)$ & 870.39 & 862.40 & 864.83 & 864.91 & 891.01 \\
Bull Put Ladder $(-2 ;-1 ;-0.5)$ & 937.86 & 1408.12 & 1859.54 & 1676.87 & 2760.30 \\
Bear Call Ladder $(0.5 ;+1 ;+2)$ & 960.86 & 1483.93 & 1991.29 & 1814.12 & 2970.01 \\
\hline
\end{tabular}

Table A2. Average cost (maximum loss) of vertical spreads for each category of implied volatility (\% of one option contract).

\begin{tabular}{cccccc}
\hline & \multicolumn{5}{c}{ Implied Volatility Category } \\
\hline Variant & $\mathbf{0 - 2 0}$ & $\mathbf{2 0 - 8 0}$ & $\mathbf{8 0 - 9 0}$ & $\mathbf{9 0 - 9 5}$ & $\mathbf{9 5 - 1 0 0}$ \\
\hline Bull Call Spread $(0.5 ;+1)$ & $0.29 \%$ & $0.36 \%$ & $0.43 \%$ & $0.54 \%$ & $0.56 \%$ \\
Bull Call Spread $(1 ;+2)$ & $0.46 \%$ & $0.62 \%$ & $0.75 \%$ & $0.95 \%$ & $1,00 \%$ \\
Bull Call Spread $(0.5 ;+2)$ & $0.75 \%$ & $0.98 \%$ & $1.18 \%$ & $1.49 \%$ & $1.56 \%$ \\
Bear Put Spread $(-1 ;-0.5)$ & $0.28 \%$ & $0.36 \%$ & $0.45 \%$ & $0.58 \%$ & $0.67 \%$ \\
Bear Put Spread $(-2 ;-1)$ & $0.53 \%$ & $0.71 \%$ & $0.88 \%$ & $1.13 \%$ & $1.3 \%$ \\
Bear Put Spread $(-2 ;-0.5)$ & $0.81 \%$ & $1.07 \%$ & $1.33 \%$ & $1.71 \%$ & $1.96 \%$ \\
Bull Put Spread $(-1 ;-0.5)$ & $0.32 \%$ & $0.4 \%$ & $0.48 \%$ & $0.59 \%$ & $0.63 \%$ \\
Bull Put Spread $(-2 ;-1)$ & $0.66 \%$ & $0.82 \%$ & $0.98 \%$ & $1.22 \%$ & $1.29 \%$ \\
Bull Put Spread $(-2 ;-0.5)$ & $0.98 \%$ & $1.22 \%$ & $1.45 \%$ & $1.82 \%$ & $1.92 \%$ \\
Bear Call Spread $(0.5 ;+1)$ & $0.31 \%$ & $0.4 \%$ & $0.49 \%$ & $0.64 \%$ & $0.73 \%$ \\
Bear Call Spread $(1 ;+2)$ & $0.73 \%$ & $0.91 \%$ & $1.1 \%$ & $1.4 \%$ & $1.59 \%$ \\
Bear Call Spread $(0.5 ;+2)$ & $1.04 \%$ & $1.31 \%$ & $1.6 \%$ & $2.03 \%$ & $2.32 \%$ \\
Bull Put Ladder $(-2 ;-1 ;-0.5)$ & $1.05 \%$ & $1.93 \%$ & $3.14 \%$ & $3.76 \%$ & $6.99 \%$ \\
Bear Call Ladder $(0.5 ;+1 ;+2)$ & $1.08 \%$ & $2.06 \%$ & $3.39 \%$ & $4.09 \%$ & $7.57 \%$ \\
\hline
\end{tabular}




\section{Appendix B. Vertical Spread Option Strategy Results}

Table A3. Bear put spread, bear call spread, and bull put ladder results.

\begin{tabular}{|c|c|c|c|c|c|c|c|c|c|}
\hline $\begin{array}{l}\text { Bear Put } \\
\text { Spread } \\
(-1 ;-0.5)\end{array}$ & $\begin{array}{l}\text { Bear Put } \\
\text { Spread } \\
(-2 ;-1)\end{array}$ & $\begin{array}{l}\text { Bear Put } \\
\text { Spread } \\
(-2 ;-0.5)\end{array}$ & $\begin{array}{c}\text { Bear Call } \\
\text { Spread } \\
(0.5 ;+1)\end{array}$ & $\begin{array}{c}\text { Bear Call } \\
\text { Spread } \\
(1 ;+2)\end{array}$ & $\begin{array}{c}\text { Bear Call } \\
\text { Spread } \\
(0.5 ;+2)\end{array}$ & $\begin{array}{c}\text { Bull Put } \\
\text { Ladder } \\
(-2 ;-1 ;-0.5)\end{array}$ & $\begin{array}{l}\text { Category of } \\
\text { Price Changes }\end{array}$ & $\begin{array}{l}\text { Category } \\
\text { of IV }\end{array}$ & $\begin{array}{l}\text { Number of } \\
\text { Observations }\end{array}$ \\
\hline $0.41 \%$ & $0.84 \%$ & $1.25 \%$ & $0.37 \%$ & $0.62 \%$ & $0.99 \%$ & $30.01 \%$ & $(-\infty ;-20 \%)$ & $20-80$ & 14 \\
\hline $0.56 \%$ & $1.14 \%$ & $1.7 \%$ & $0.51 \%$ & $0.91 \%$ & $1.42 \%$ & $33.33 \%$ & $(-\infty ;-20 \%)$ & $90-95$ & 5 \\
\hline $0.64 \%$ & $1.32 \%$ & $1.96 \%$ & $0.57 \%$ & $1.01 \%$ & $1.58 \%$ & $8.99 \%$ & $(-\infty ;-20 \%)$ & 95-100 & 11 \\
\hline $0.28 \%$ & $0.57 \%$ & $0.85 \%$ & $0.25 \%$ & $0.4 \%$ & $0.66 \%$ & $7.91 \%$ & {$[20 \% ;-10 \%)$} & $0-20$ & 18 \\
\hline $0.51 \%$ & $1.04 \%$ & $1.55 \%$ & $0.46 \%$ & $0.81 \%$ & $1.27 \%$ & $5.24 \%$ & {$[-20 \% ;-10 \%)$} & $90-95$ & 5 \\
\hline $0.62 \%$ & $1.27 \%$ & $1.89 \%$ & $0.56 \%$ & $0.98 \%$ & $1.54 \%$ & $3.43 \%$ & {$[-20 \% ;-10 \%)$} & $95-100$ & 31 \\
\hline $0.35 \%$ & $0.71 \%$ & $1.06 \%$ & $0.31 \%$ & $0.51 \%$ & $0.83 \%$ & $3.51 \%$ & {$[-10 \% ;-5 \%)$} & $0-20$ & 56 \\
\hline $0.41 \%$ & $0.83 \%$ & $1.24 \%$ & $0.37 \%$ & $0.63 \%$ & $1,00 \%$ & $2.26 \%$ & {$[-10 \% ;-5 \%)$} & $20-80$ & 147 \\
\hline $0.42 \%$ & $0.85 \%$ & $1.27 \%$ & $0.38 \%$ & $0.66 \%$ & $1.04 \%$ & $1.84 \%$ & {$[-10 \% ;-5 \%)$} & $80-90$ & 11 \\
\hline $0.6 \%$ & $1.13 \%$ & $1.72 \%$ & $0.54 \%$ & $0.96 \%$ & $1.5 \%$ & $-1.28 \%$ & {$[-10 \% ;-5 \%)$} & $90-95$ & 10 \\
\hline $0.35 \%$ & $-0.39 \%$ & $-0.04 \%$ & $0.57 \%$ & $1.01 \%$ & $1.58 \%$ & $-3.26 \%$ & {$[-5 \% ; 0 \%)$} & $90-95$ & 14 \\
\hline $0.03 \%$ & $-0.64 \%$ & $-0.62 \%$ & $0.64 \%$ & $1.14 \%$ & $1.79 \%$ & $-6.56 \%$ & {$[-5 \% ; 0 \%)$} & 95-100 & 13 \\
\hline$-0.27 \%$ & $-0.51 \%$ & $-0.78 \%$ & $-0.19 \%$ & $-0.23 \%$ & $-0.42 \%$ & $-0.45 \%$ & {$[0 \% ; 5 \%)$} & $0-20$ & 150 \\
\hline$-0.35 \%$ & $-0.69 \%$ & $-1.04 \%$ & $-0.2 \%$ & $-0.14 \%$ & $-0.34 \%$ & $-1.1 \%$ & {$[0 \% ; 5 \%)$} & $20-80$ & 361 \\
\hline$-0.42 \%$ & $-0.82 \%$ & $-1.23 \%$ & $-0.3 \%$ & $-0.24 \%$ & $-0.55 \%$ & $-2.18 \%$ & {$[0 \% ; 5 \%)$} & $80-90$ & 32 \\
\hline$-0.69 \%$ & $-1.33 \%$ & $-2.02 \%$ & $-0.16 \%$ & $0.55 \%$ & $0.39 \%$ & $-2.41 \%$ & {$[0 \% ; 5 \%)$} & 90-95 & 7 \\
\hline$-0.58 \%$ & $-1.12 \%$ & $-1.7 \%$ & $-0.19 \%$ & $0.53 \%$ & $0.34 \%$ & $-3.62 \%$ & {$[0 \% ; 5 \%)$} & 95-100 & 5 \\
\hline$-0.32 \%$ & $-0.63 \%$ & $-0.95 \%$ & $-0.36 \%$ & $-0.86 \%$ & $-1.22 \%$ & $-0.29 \%$ & {$[5 \% ; 10 \%)$} & $0-20$ & 30 \\
\hline$-0.38 \%$ & $-0.73 \%$ & $-1.11 \%$ & $-0.42 \%$ & $-0.94 \%$ & $-1.36 \%$ & $-1.23 \%$ & {$[5 \% ; 10 \%)$} & $20-80$ & 176 \\
\hline$-0.43 \%$ & $-0.84 \%$ & $-1.27 \%$ & $-0.47 \%$ & $-1.04 \%$ & $-1.52 \%$ & $-2.31 \%$ & {$[5 \% ; 10 \%)$} & $80-90$ & 35 \\
\hline$-0.57 \%$ & $-1.1 \%$ & $-1.67 \%$ & $-0.62 \%$ & $-1.37 \%$ & $-1.99 \%$ & $-2.96 \%$ & {$[5 \% ; 10 \%)$} & 90-95 & 6 \\
\hline$-0.6 \%$ & $-1.16 \%$ & $-1.76 \%$ & $-0.65 \%$ & $-0.94 \%$ & $-1.59 \%$ & $-4.38 \%$ & {$[5 \% ; 10 \%)$} & 95-100 & 6 \\
\hline
\end{tabular}

Table A4. Bull put spread, bull call spread, and bear call ladder results.

\begin{tabular}{|c|c|c|c|c|c|c|c|c|c|}
\hline $\begin{array}{c}\text { Bull Call } \\
\text { Spread } \\
(0.5 ;+1)\end{array}$ & $\begin{array}{c}\text { Bull Call } \\
\text { Spread } \\
(1 ;+2)\end{array}$ & $\begin{array}{c}\text { Bull Call } \\
\text { Spread } \\
(0.5 ;+2)\end{array}$ & $\begin{array}{l}\text { Bull Put } \\
\text { Spread } \\
(-1 ;-0.5)\end{array}$ & $\begin{array}{l}\text { Bull Put } \\
\text { Spread } \\
(-2 ;-1)\end{array}$ & $\begin{array}{c}\text { Bull Put } \\
\text { Spread } \\
(-2 ;-0.5)\end{array}$ & $\begin{array}{c}\text { Bear Call } \\
\text { Ladder } \\
(0.5 ;+1 ;+2)\end{array}$ & $\begin{array}{c}\text { Category of } \\
\text { Price Changes }\end{array}$ & $\begin{array}{c}\text { Category } \\
\text { of IV }\end{array}$ & $\begin{array}{l}\text { Number of } \\
\text { Observations }\end{array}$ \\
\hline$-0.37 \%$ & $-0.62 \%$ & $-0.99 \%$ & $-0.41 \%$ & $-0.84 \%$ & $-1.25 \%$ & $-1.68 \%$ & $(-\infty ;-20 \%)$ & $20-80$ & 14 \\
\hline$-0.49 \%$ & $-0.86 \%$ & $-1.35 \%$ & $-0.54 \%$ & $-1.1 \%$ & $-1.63 \%$ & $-1.8 \%$ & $(-\infty ;-20 \%)$ & $80-90$ & 4 \\
\hline$-0.51 \%$ & $-0.91 \%$ & $-1.42 \%$ & $-0.56 \%$ & $-1.14 \%$ & $-1.7 \%$ & $-1.71 \%$ & $(-\infty ;-20 \%)$ & $90-95$ & 5 \\
\hline$-0.57 \%$ & $-1.01 \%$ & $-1.58 \%$ & $-0.64 \%$ & $-1.32 \%$ & $-1.96 \%$ & $-8.05 \%$ & $(-\infty ;-20 \%)$ & 95-100 & 11 \\
\hline$-0.25 \%$ & $-0.4 \%$ & $-0.66 \%$ & $-0.28 \%$ & $-0.57 \%$ & $-0.85 \%$ & $-0.67 \%$ & {$[-20 \% ;-10 \%)$} & $0-20$ & 18 \\
\hline$-0.38 \%$ & $-0.65 \%$ & $-1.03 \%$ & $-0.42 \%$ & $-0.86 \%$ & $-1.28 \%$ & $-1.31 \%$ & {$[-20 \% ;-10 \%)$} & $20-80$ & 137 \\
\hline$-0.49 \%$ & $-0.86 \%$ & $-1.35 \%$ & $-0.54 \%$ & $-1.11 \%$ & $-1.65 \%$ & $-2.32 \%$ & {$[-20 \% ;-10 \%)$} & $80-90$ & 34 \\
\hline$-0.46 \%$ & $-0.81 \%$ & $-1.27 \%$ & $-0.51 \%$ & $-1.04 \%$ & $-1.55 \%$ & $-2.72 \%$ & {$[-20 \% ;-10 \%)$} & $90-95$ & 5 \\
\hline$-0.56 \%$ & $-0.98 \%$ & $-1.54 \%$ & $-0.62 \%$ & $-1.27 \%$ & $-1.89 \%$ & $-6.74 \%$ & {$[-20 \% ;-10 \%)$} & 95-100 & 31 \\
\hline$-0.31 \%$ & $-0.51 \%$ & $-0.83 \%$ & $-0.35 \%$ & $-0.71 \%$ & $-1.06 \%$ & $-0.43 \%$ & {$[-10 \% ;-5 \%)$} & $0-20$ & 56 \\
\hline$-0.37 \%$ & $-0.63 \%$ & $-1.00 \%$ & $-0.41 \%$ & $-0.83 \%$ & $-1.24 \%$ & $-1.21 \%$ & {$[-10 \% ;-5 \%)$} & $20-80$ & 147 \\
\hline$-0.38 \%$ & $-0.66 \%$ & $-1.04 \%$ & $-0.42 \%$ & $-0.85 \%$ & $-1.27 \%$ & $-2.39 \%$ & {$[-10 \% ;-5 \%)$} & $80-90$ & 11 \\
\hline$-0.54 \%$ & $-0.96 \%$ & $-1.5 \%$ & $-0.6 \%$ & $-1.13 \%$ & $-1.72 \%$ & $-2.69 \%$ & {$[-10 \% ;-5 \%)$} & $90-95$ & 10 \\
\hline$-0.52 \%$ & $-0.92 \%$ & $-1.45 \%$ & $-0.58 \%$ & $-1,00 \%$ & $-1.58 \%$ & $-5.6 \%$ & {$[-10 \% ;-5 \%)$} & $95-100$ & 9 \\
\hline$-0.27 \%$ & $-0.44 \%$ & $-0.71 \%$ & $-0.21 \%$ & $-0.25 \%$ & $-0.46 \%$ & $-0.5 \%$ & {$[-5 \% ; 0 \%)$} & $0-20$ & 128 \\
\hline$-0.34 \%$ & $-0.58 \%$ & $-0.92 \%$ & $-0.15 \%$ & $0.04 \%$ & $-0.12 \%$ & $-1.3 \%$ & {$[-5 \% ; 0 \%)$} & $20-80$ & 279 \\
\hline$-0.35 \%$ & $-0.59 \%$ & $-0.94 \%$ & $-0.03 \%$ & $0.17 \%$ & $0.14 \%$ & $-2.69 \%$ & {$[-5 \% ; 0 \%)$} & $80-90$ & 12 \\
\hline$-0.57 \%$ & $-1.01 \%$ & $-1.58 \%$ & $-0.35 \%$ & $0.39 \%$ & $0.04 \%$ & $-2.79 \%$ & {$[-5 \% ; 0 \%)$} & $90-95$ & 14 \\
\hline$-0.64 \%$ & $-1.14 \%$ & $-1.79 \%$ & $-0.03 \%$ & $0.64 \%$ & $0.62 \%$ & $-6.83 \%$ & {$[-5 \% ; 0 \%)$} & $95-100$ & 13 \\
\hline $0.19 \%$ & $0.23 \%$ & $0.42 \%$ & $0.27 \%$ & $0.51 \%$ & $0.78 \%$ & $-0.24 \%$ & {$[0 \% ; 5 \%)$} & $0-20$ & 150 \\
\hline $0.2 \%$ & $0.14 \%$ & $0.34 \%$ & $0.35 \%$ & $0.69 \%$ & $1.04 \%$ & $-1.34 \%$ & {$[0 \% ; 5 \%)$} & $20-80$ & 361 \\
\hline $0.3 \%$ & $0.24 \%$ & $0.55 \%$ & $0.42 \%$ & $0.82 \%$ & $1.23 \%$ & $-2.76 \%$ & {$[0 \% ; 5 \%)$} & $80-90$ & 32 \\
\hline $0.16 \%$ & $-0.55 \%$ & $-0.39 \%$ & $0.69 \%$ & $1.33 \%$ & $2.02 \%$ & $-3.55 \%$ & {$[0 \% ; 5 \%)$} & $90-95$ & 7 \\
\hline $0.19 \%$ & $-0.53 \%$ & $-0.34 \%$ & $0.58 \%$ & $1.12 \%$ & $1.7 \%$ & $-4.55 \%$ & {$[0 \% ; 5 \%)$} & $95-100$ & 5 \\
\hline
\end{tabular}


Table A4. Cont.

\begin{tabular}{|c|c|c|c|c|c|c|c|c|c|}
\hline $\begin{array}{l}\text { Bull Call } \\
\text { Spread } \\
(0.5 ;+1)\end{array}$ & $\begin{array}{c}\text { Bull Call } \\
\text { Spread } \\
(1 ;+2)\end{array}$ & $\begin{array}{c}\text { Bull Call } \\
\text { Spread } \\
(0.5 ;+2)\end{array}$ & $\begin{array}{c}\text { Bull Put } \\
\text { Spread } \\
(-1 ;-0.5)\end{array}$ & $\begin{array}{l}\text { Bull Put } \\
\text { Spread } \\
(-2 ;-1)\end{array}$ & $\begin{array}{c}\text { Bull Put } \\
\text { Spread } \\
(-2 ;-0.5)\end{array}$ & $\begin{array}{c}\text { Bear Call } \\
\text { Ladder } \\
(0.5 ;+1 ;+2)\end{array}$ & $\begin{array}{c}\text { Category of } \\
\text { Price Changes }\end{array}$ & $\begin{array}{l}\text { Category } \\
\text { of IV }\end{array}$ & $\begin{array}{l}\text { Number of } \\
\text { Observations }\end{array}$ \\
\hline $0.36 \%$ & $0.86 \%$ & $1.22 \%$ & $0.32 \%$ & $0.63 \%$ & $0.95 \%$ & $3.15 \%$ & {$[5 \% ; 10 \%)$} & $0-20$ & 30 \\
\hline $0.47 \%$ & $1.04 \%$ & $1.52 \%$ & $0.43 \%$ & $0.84 \%$ & $1.27 \%$ & $0.21 \%$ & {$[5 \% ; 10 \%)$} & $80-90$ & 35 \\
\hline $0.62 \%$ & $1.37 \%$ & $1.99 \%$ & $0.57 \%$ & $1.1 \%$ & $1.67 \%$ & $-0.9 \%$ & {$[5 \% ; 10 \%)$} & 90-95 & 6 \\
\hline $0.65 \%$ & $0.94 \%$ & $1.59 \%$ & $0.6 \%$ & $1.16 \%$ & $1.76 \%$ & $-2.74 \%$ & {$[5 \% ; 10 \%)$} & $95-100$ & 6 \\
\hline $0.5 \%$ & $1.12 \%$ & $1.62 \%$ & $0.45 \%$ & $0.89 \%$ & $1.34 \%$ & $7.65 \%$ & {$[10 \% ; 20 \%)$} & $80-90$ & 45 \\
\hline $0.62 \%$ & $1.36 \%$ & $1.97 \%$ & $0.56 \%$ & $1.09 \%$ & $1.66 \%$ & $5.59 \%$ & {$[10 \% ; 20 \%)$} & 90-95 & 35 \\
\hline $0.62 \%$ & $1.34 \%$ & $1.96 \%$ & $0.57 \%$ & $1.11 \%$ & $1.67 \%$ & $6.16 \%$ & {$[10 \% ; 20 \%)$} & $95-100$ & 4 \\
\hline $0.6 \%$ & $1.35 \%$ & $1.95 \%$ & $0.55 \%$ & $1.06 \%$ & $1.61 \%$ & $14.36 \%$ & {$[20 \% ;+\infty)$} & $80-90$ & 6 \\
\hline $0.59 \%$ & $1.3 \%$ & $1.89 \%$ & $0.54 \%$ & $1.04 \%$ & $1.58 \%$ & $10.81 \%$ & {$[20 \% ;+\infty)$} & $90-95$ & 9 \\
\hline $0.71 \%$ & $1.55 \%$ & $2.26 \%$ & $0.65 \%$ & $1.26 \%$ & $1.91 \%$ & $13.44 \%$ & {$[20 \% ;+\infty)$} & $95-100$ & 7 \\
\hline
\end{tabular}

\section{References}

1. Zou, G.; Chau, K.W. Effects of International Crude Oil Prices on Energy Consumption in China. Energies 2020, 13, 3891.

2. Ewing, B.T.; Malik, F. Volatility transmission between gold and oil futures under structural breaks. Int. Rev. Econ. Financ. 2013, 25, 113-121.

3. Chen, $\mathrm{R} . ; \mathrm{Xu}, \mathrm{J}$. Forecasting volatility and correlation between oil and gold prices using a novel multivariate GAS model. Energy Econ. 2019, 78, 379-391.

4. Nguyen, C.; Bhatti, M.I.; Komorníková, M.; Komorník, J. Gold price and stock markets nexus under mixed-copulas. Econ. Model. 2016, 58, 283-292.

5. Sari, R.; Hammoudeh, S.; Soytas, U. Dynamics of oil price, precious metal prices and exchange rate. Energy Econ. 2010, 32, 351-362.

6. Popp, J.; Oláh, J.; Fekete, M.F.; Lakner, Z.; Máté, D. The Relationship between Prices of Various Metals, Oil and Scarcity. Energies 2018, 11, 2392.

7. Wu, F.; Guan, Z.; Myers, R.J. Volatility spillover effects and cross hedging in corn and crude oil futures. J. Futures Mark. 2011, 31, 1052-1075.

8. Walid, M.; Shawkat, H.; Duc, K.; Seong, Y. Dynamic spillovers among major energy and cereal commodity prices. Energy Econ. 2014, 43, 225-243.

9. Taghizadeh-Hesary, F.; Rasoulinezhad, E.; Yoshino, N. Volatility Linkages between Energy and Food Prices: Case of Selected Asian Countries. Asian Development Bank Institute Working Paper 829. Available online: https://www.adb.org/sites/default/files/publication/411176/adbi-wp829.pdf (accessed on 15 April 2020).

10. Vo, D.H.; Vu, T.N.; Vo, A.T.; McAleer, M. Modeling the Relationship between Crude Oil and Agricultural Commodity Prices. Energies 2019, 12, 1344.

11. Villar, J.A.; Joutz, F.L. The Relationship between Crude Oil and Natural Gas Prices; Energy Information Administration, Office of Oil and Natural Gas: Washington, DC, USA, 2006; pp. 1-43.

12. Ji, Q.; Geng, J.B.; Fan, Y. Separated influence of crude oil prices on regional natural gas import prices. Energy Policy 2014, 70, 96-105.

13. Lin, B.; Li, J. The spillover effects across natural gas and oil markets: Based on the VEC-MGARCH framework. Appl. Energy 2015, 155, 229-241. [CrossRef]

14. Ji, Q.; Geng, J.B.; Aviral, K.T. Information spillovers and connectedness networks in the oil and gas markets. Energy Econ. 2018, 75, 71-84. [CrossRef]

15. Zhang, D.Y.; Shi, M.; Shi, X. Oil indexation, market fundamentals, and natural gas prices: An investigation of the Asian premium in natural gas trade. Energy Econ. 2018, 69, 33-41. [CrossRef]

16. Baffes, J. Oil spills on other commodities. Resour. Policy 2007, 32, 126-134. [CrossRef]

17. Ji, Q.; Fan, Y. How does oil price volatility affect non-energy commodity markets? Appl. Energy 2012, 89, 273-280. [CrossRef]

18. Demiralay, S.; Hourvouliades, N.; Fassas, A. Dynamic co-movements and directional spillovers among energy futures. Stud. Econ. Financ. 2020. [CrossRef] 
19. Liu, T.; Gong, X. Analyzing time-varying volatility spillovers between the crude oil markets using a new method. Energy Econ. 2020, 87, 1-11. [CrossRef]

20. Reboredo, J.C.; Rivera-Castro, M.A. A wavelet decomposition approach to crude oil price and exchange rate dependence. Econ. Model. 2013, 32, 42-57. [CrossRef]

21. Golub, S. Oil prices and exchange rates. Econ. J. 1983, 93, 576-593. [CrossRef]

22. Zhang, Y.J.; Fan, Y.; Tsai, H.T.; Wei, Y.M. Spillover effect of US dollar exchange rate on oil prices. J. Policy Model. 2008, 30, 973-991. [CrossRef]

23. De Truchis, G.; Keddad, B. On the risk comovements between the crude oil market and U.S. dollar exchange rates. Econ. Model. 2016, 52, 206-215. [CrossRef]

24. Al Rahahleh, N.; Bhatti, M.I. Co-movement measure of information transmission on international equity markets. Phys. A Stat. Mech. Appl. 2017, 470, 119-131. [CrossRef]

25. Jones, C.; Kaul, G. Oil and the stock markets. J. Financ. 1996, 51, 463-491. [CrossRef]

26. Basher, S.A.; Sadorsky, P. Oil price risk and emerging stock markets. Glob. Financ. J. 2006, 17, $224-251$. [CrossRef]

27. Nandha, M.; Faff, R. Does oil move equity prices? A global view. Energy Econ. 2008, 30, 986-997. [CrossRef]

28. Hsiao, C.Y.; Lin, W.; Wei, X.; Yan, G.; Li, S.; Sheng, N. The Impact of International Oil Prices on the Stock Price Fluctuations of China's Renewable Energy Enterprises. Energies 2019, 12, 4630. [CrossRef]

29. Malik, F.; Hammoudeh, S. Shock and volatility transmission on the oil, US and Gulf equity markets. Int. Rev. Econ. Financ. 2007, 16, 357-368. [CrossRef]

30. Arouri, M.E.H.; Jouini, J.; Nguyen, D. Volatility spillovers between oil prices and stock sector returns: Implications for portfolio management. J. Int. Money Financ. 2011, 30, 1387-1405. [CrossRef]

31. Maghyereh, A.I.; Awartani, B. Oil price uncertainty and equity returns. J. Financ. Econ. Policy 2016, 8, 64-79. [CrossRef]

32. Arouri, M.; Jouini, J.; Nguyen, K.D. On the impacts of oil price fluctuations on European equity markets: Volatility spillover and hedging effectiveness. Energy Econ. 2012, 34, 611-617.

33. Black, F.; Scholes, M. The pricing of option and corporate liabilities. J. Financ. Econ. 1973, 3, 637-654.

34. Black, F. The pricing of commodity contracts. J. Political Econ. 1976, 81, 167-179. [CrossRef]

35. Fassas, A.; Siriopoulos, C. Implied volatility indices-A review. Q. Rev. Econ. Financ. 2020. [CrossRef]

36. Siriopoulos, C.; Fassas, A. Dynamic relations of uncertainty expectations: A conditional assessment of implied volatility indices. Rev. Deriv. Res. 2013, 16, 233-266. [CrossRef]

37. Lopez, R. Volatility contagion across commodity, equity, foreign exchange and Treasury bond markets. Appl. Econ. Lett. 2014, 21, 646-650. [CrossRef]

38. Kenourgios, D. On financial contagion and implied market volatility. Int. Rev. Financ. Anal. 2014, 34, 21-30. [CrossRef]

39. Maghyereh, A.I.; Awartani, B.; Bouri, E. The directional volatility connectedness between crude oil and equity markets: New evidence from implied volatility indexes. Energy Econ. 2016, 57, 78-93. [CrossRef]

40. Ji, Q.; Bouri, E.; Roubaud, D. Dynamic network of implied volatility transmission among US equities, strategic commodities, and BRICS equities. Int. Rev. Financ. Anal. 2018, 57, 1-12. [CrossRef]

41. Badshah, I.U.; Bekiros, S.; Lucey, B.M.; Uddin, G.S. Asymmetric linkages among the fear index and emerging market volatility indices. Emerg. Mark. Rev. 2018, 37, 17-31. [CrossRef]

42. Bouri, E.; Lucey, B.; Roubaud, D. Dynamics and determinants of spillovers across the option-implied volatilities of US equities. Q. Rev. Econ. Financ. 2020, 75, 257-264. [CrossRef]

43. Giot, P. Relationships between implied volatility indexes and stock index returns. J. Portf. Manag. 2005, 31, 92-100.

44. Banerjee, P.S.; Doran, J.S.; Peterson, D.R. Implied volatility and future portfolio returns. J. Bank. Financ. 2007, 31, 3183-3199.

45. Hibbert, A.M.; Daigler, R.T.; Dupoyet, B. A behavioral explanation for the negative asymmetric return-volatility relation. J. Bank. Financ. 2008, 32, 2254-2266. [CrossRef]

46. Whaley, R.E. Understanding the VIX. J. Portf. Manag. 2009, 35, 98-105. [CrossRef]

47. Zhu, M. Return distribution predictability and its implications for portfolio selection. Int. Rev. Econ. Financ. 2013, 27, 209-223.

48. Blair, B.; Poon, S.H.; Taylor, S.J. Forecasting S\&P 100 volatility: The incremental information content of implied volatilities and high frequency index returns. J. Econom. 2001, 105, 5-26. 
49. Poon, S.H.; Granger, C.W. Forecasting volatility in financial markets: A review. J. Econ. Lit. 2003, 41, 478-539. [CrossRef]

50. Poon, S.H.; Granger, C.W.J. Practical issues in forecasting volatility. Financ. Anal. J. 2005, 61, 45-56. [CrossRef]

51. Gonzalez-Perez, M.T. Model-free volatility indexes in the financial literature: A review. Int. Rev. Econ. Financ. 2015, 40, 141-159. [CrossRef]

52. Amaitiek, O.; Šoltés, V. Inverse vertical ratio put spread strategy and its application in hedging against a price drop. J. Adv. Stud. Financ. 2010, 1, 100-107.

53. Šoltés, V.; Rusnáková, M. Hedging Against a Price Drop Using the Inverse Vertical Ratio Put Spread Strategy Formed by Barrier Options. Eng. Econ. 2013, 24, 18-27.

54. Šoltés, M. Using Option Strategies in Trading. Procedia Soc. Behav. Sci. 2014, 110, 979-985. [CrossRef]

55. Rusnáková, M.; Šoltés, V.; Szabo, Z.K. Short Combo Strategy Using Barrier Options and its Application in Hedging. Procedia Econ. Financ. 2015, 32, 166-179. [CrossRef]

56. Sheu, H.-J.; Wei, J.-C.H. Effective options trading strategies based on volatility forecasting recruiting investor sentiment. Expert Syst. Appl. 2011, 38, 585-596. [CrossRef]

57. Cohen, G. The Bible of Option Strategies: The Definitive Guide for Practical Trading Strategies; Pearson Education: Prentice Hall, NJ, USA, 2005; pp. 89-118.

58. QuikVol Tool. WTI(LO) Volatility and Skew. Available online: https://www.cmegroup.com/tools-information/ quikstrike/pricing-volatility-strategy-tools/quikvol-tool.html (accessed on 15 April 2020).

59. Soini, V.; Lorentzen, S. Option prices and implied volatility in the crude oil market. Energy Econ. 2019, 83, 515-539. [CrossRef]

60. Fassas, A.; Hourvouliades, N. VIX Futures as a Market Timing Indicator. J. Risk Financ. Manag. 2019, $12,113$.

(C) 2020 by the authors. Licensee MDPI, Basel, Switzerland. This article is an open access article distributed under the terms and conditions of the Creative Commons Attribution (CC BY) license (http://creativecommons.org/licenses/by/4.0/). 